\title{
AZ OLVASÁSI KÉSZSÉG VIZSGÁLATA AFÁZIÁS BETEGEKNÉL A HÁROMUTAS OLVASÁSVIZSGÁLÓ TESZTTEL
}

\section{Szerzők:}

Dankovics Natália

Debreceni Egyetem Gyermeknevelési és

Felnőttképzési Kar

Mokuolu Tímea

Széchenyi István Egyetem Apáczai Csere János Kar

Pelyvás Károlyné

Református Egységes Gyógypedagógiai

Intézmény Debreceni Tagintézménye

Első szerző e-mail címe: dankovicsnatalia@gmail.com

\section{Lektorok:}

Macher Mónika

ELTE Bárczi Gusztáv Gyógypedagógiai

Kar

Schéder Veronika

Debreceni Egyetem Gyermeknevelési és

Felnőttképzési Kar

Szabó Edina

Debreceni Egyetem

Mező Katalin

Debreceni Egyetem

Dankovics, Natália; Mokuolu, Tímea; Pelyvás, Károlyné (2017): Az olvasási készség vizsgálata afáziás betegeknél a háromutas olvasásvizsgáló teszttel Különleges Bánásmód, III. évf. 2017/2. szám, 87-116. DOI 10.18458/KB.2017.2.87

\begin{abstract}
Absztrakt
Az afázia, a nyelvi képesség szerzett zavara a szóbeli és az írásbeli kommunikációt egyaránt érinti (Osmanné, 1997, Gósy, 2005). Míg a szóbeli nyelvhasználat vizsgálatára több jól használható, a beteg nyelvi képességének állapotáról átfogó, hiteles képet adó eljárás áll rendelkezésre (Osmanné, 1983, 2007), addig az olvasási készség vizsgálatához csak a WAB olvasásvizsgálat néven ismert teszt érhető el magyar nyelven (Net 1). Mivel ez az eljárás tapasztalatunk szerint nehézkes, értékelése nem egyértelmü, a kapott eredmény pedig nem tükrözi a beteg foglalkozások alatt nyújtott olvasási teljesítményét, célul tüztük ki egy új diagnosztikai eljárás kidolgozását.

Vizsgálóeljárásunk elméleti alapját Ellis és Young egyesitett szófelismerési modellje adja (Ellis, 2004). Célunk az egyes olvasási utakon nyújtott teljesítmény feltárása volt annak érdekében, hogy a megtartottnak bizonyult útból kiindulva célzott terápiás módszer alkalmazását tegyük lehetővé a sérült utak helyreállításához.

Motoros túlsúlyú szenzomotoros afáziás betegek körében végzett első vizsgálataink tapasztalata, hogy anyagunk egyszerüen, gördülékenyen használható. Az eredmények azt igazolják, hogy a teszt alkalmas a különböző olvasási utakon nyújtott teljesítmények mérésére, ebből következően megfelelően támpontot ad a terápiás folyamathoz.
\end{abstract}

Kulcsszavak: afázia, olvasási képesség, olvasási zavar, egyesített szófelismerési modell

Diszciplina: pedagógia 


\section{Abstract}

Aphasia is an acquired disorder of previously intact language ability that can affect both oral and written language (Osmanné, 1997, Gósy, 2005). Whilst there are a few fairly useable methods available that can provide a global and true picture of the patient's linguistic abilities in oral language (Osmanné, 1983, 2007), there is only one assessment method in use in Hungarian for measuring the reading skills and it is a part of the Western Aphasia Battery (Net 1). This assessment does not enable unambiguous interpretation at several points, the scoring method is sometimes not clear and most importantly the results do not mirror the patient's performance that had been previously observed. This is why we have decided to develop a new diagnostic test.

Our investigation of the reading process in aphasia is based on Ellis and Young's theory of the dual-route model (Ellis, 2004). Our aim was to assess the patients' performance in each reading process (route) so a therapy method can be created that is based on the intact reading process and supports the recovery of the damaged routes.

The data for our pilot study was collected from patients who had both motor and sensory disturbance with motor dominance. The use of our testing method was smooth and easy in practice. The results confirm that the method is suitable to use in measuring the performance on different reading routes that can give a guidance designing the treatment approach.

Keywords: aphasia, reading skills, reading disorder, theory of the dual-route model

\section{Disciplines: pedagogy}

\section{BEVEZETÉS}

Ha az ember kommunikációs képessége váratlanul sérülést szenved vagy elveszik, az sokszor katasztrofális következménnyel jár. A nyelvi veszteség a beteg munkájának, szociális helyzetének, rekreációs lehetőségeinek és sok más, az egyéni lét stabilitásáért felelös faktornak az elveszését vonhatja maga után (Swanberg és tsai, 2007).

Afáziának nevezzük a már kialakult nyelvi képesség egy vagy több összetevőjének olyan tartós zavarát, amely többnyire lokális (körülírható), elsősorban a domináns agyféltekében található, a nyelv tárolásáért és müködtetéséért felelős területeket ért agyi sérülés következtében jön létre, a nyelvi kompetenciát és performanciát egyaránt érinti, és rendszerint a szóbeli és az írásbeli nyelvhasználatra is kiterjed (Osmanné, 1997, Gósy, 2005).

A felépülés minden beszéd- és nyelvi zavarból több tényező függvénye, abban azonban a legtöbb klinikus egyetért, hogy a tervszerü beszédterápia hatékonyan befolyásolhatja a folyamatot (Basso, 1989, Helm-Estabrooks és tsai, 2004). A szerzett beszédzavarok kezelése a gyakorlatban minden esetben összefonódik a betegek folyamatos vizsgálatával (Krasznárné és Feketéné, 2005).

A terápia során az elsődleges cél a hangzó beszéd helyreállítása szokott lenni, míg az írott nyelvi kommunikáció fejlesztése gyakran mellékes marad (Carlomagno és tsai, 1994, Hillis, 2007, Obregón, 2008). Pedig az írás és olvasás az internet és a különböző elektronikus eszközök gyors terjedésének köszönhetően egyre nagyobb szerepet töltenek be az emberek mindennapjaiban, így az agysérülést követően ezen képességek zavara önmagában is negatívan befolyásolhatja az afáziás személyek szociális interakcióit és csökkentheti az információhoz jutás csatornáit (Hillis, 2007, Beeson és Rapcsak, 2006). Éppen ezért Hillis (2007) fontosnak tartja, hogy a teljes neurológiai vizsgálatnak agyvérzés gyanúja esetén legyen szerves része az olvasás és írás vizsgálata is.

Míg a szóbeli nyelvi állapot feltérképezésére több, magyar nyelvre is lefordított és a gyakorlatban is sikeresen használt eljárás áll a logopédusok rendelkezésére (Osmanné, 2007), 
addig az olvasási és írási készségek vizsgálatához magyarul az egyetlen hozzáférhető és használatban lévő eljárás a Kertesz (1982) által kidolgozott Western Aphasia Battery (WAB) olvasást és írást vizsgáló altesztje. Ez azonban a WAB szóbeli nyelvi képességet vizsgáló részénél sokkal kevésbé kidolgozott, ezen kívül használata során több ponton is nehézségeket, kétértelmüségeket tapasztaltunk. A vizsgálóeljárások hiányát pótolandó, egy új diagnosztikai eszköz kidolgozására tettünk kísérletet, mely az olvasási képességet hivatott vizsgálni afáziás betegeknél. Eljárásunknak a Háromutas Olvasásvizsgáló Teszt (HOT) nevet adtuk. Jelen tanulmány célja ennek az új eljárásnak, valamint első vizsgálati tapasztalatainknak bemutatása a WAB olvasást vizsgáló szubtesztben elért teljesítményekkel összevetve. A vizsgálat alanyaival mindkét eljárás felvételre került, az eredmények pedig az egyes olvasási szinteken nyújtott teljesítmény alapján kerültek összevetésre. A párhuzamba állítást nemcsak az indokolja, hogy ez a két olvasást vizsgáló eljárás létezik magyar nyelven, hanem az is, hogy szerkezetük hasonló felépítést követ: mindkettő ugyanazon stratégiák alkalmazását hivatott feltárni, melyek az olvasási folyamatot együttesen lehetővé teszik.

\section{A SZERZETT OLVASÁSI ZAVAR}

Olvasás közben a nyelv vizuálisan kódolt egységeit jelentéssel bíró akusztikus szimbólumokká kódoljuk, miközben elménkben bonyolult pszichikus folyamatok mennek végbe. Az olvasás tanult képesség, mely kognitív és neurális szinten egyaránt genetikusan kódolt, idegrendszeri előhuzalozottsággal rendelkező, a fejlődés természetes folyamatában kibontakozó humán képességeinkre, legföképpen a nyelvi képességre épül rá (Csépe, 2006, Tóth, 2002).

Nyelvi zavarral járó agysérülések gyakori következménye az olvasás (és az írás) készségének károsodása, melyet szerzett diszlexiának (Osmanné, 1997, Ellis, 2004, Gósy, 2005, Helm-Estabrooks és tsai, 2004) vagy alexiának szokás nevezni (Cherney, 2004, Hillis, 2007, Beeson és Rapcsak, 2006).

A jelenség kutatása a XIX. század végén kezdődött, amikor az agy egyes területeihez a tudósok megpróbáltak bizonyos funkciókat rendelni. Ezt a nézetet szokás neuroanatómiai (Cherney, 2004) vagy lokalizációs megközelitésnek (Ahlsén, 2006) nevezni. Ennek megfelelően az olvasásban megjelenő különböző nehézségeket megpróbálták konkrét agyterületeknek megfeleltetni.

A tizenkilencedik század kiemelkedő neurológusa, Jules Déjerine 1891-ben mutatta be páciensét, aki egy baleset következtében hirtelen elvesztette az olvasási és írási képességét, valamint nehézségei voltak a számok és a zenei jelek értelmezésében is. Az olvasás számára sem betüzéssel, sem pedig szavak felismerésével nem volt lehetséges. A hangosan betüzött szavakat sem tudta azonosítani. Az írásban is hasonló tüneteket produkált, másolni azonban képes volt. Páciense halála után az agyát megvizsgálva Déjerine a bal anguláris gyrust érintő infarktus nyomait találta. Ebből arra a következtetésre jutott, hogy a bal parietális terület sérülése okozta az alexiát és agráfiát azzal, hogy lerombolta a vizuális szóképek kérgi központját (Beeson és Rapcsak, 2006, Cherney, 2004, Swanberg és tsai, 2007).

A legtöbb emberben a nyelvi folyamatok túlnyomó többségéért a domináns - jellemzően a bal - agyfélteke a felelős. A megfigyelt nyelvi feldolgozást irányító központok mérete pedig általában látványosan nagyobb a domináns féltekében, mint a szubdomináns félteke megfelelő területein. Fejlődési diszlexiásokon végzett vizsgálatok eredményei arra utalnak, hogy az olvasás folyamatában ilyen, kiemelkedő fontosságú agyi képlet a planum temporale, melyről tudott, hogy a Wernicke-terület részeként jelentős szerepet játszik a fonológiai feldolgozásban (Galaburda és Kemper, 1979, Galaburda és tsai, 1985, Csépe, 2006). Ez azonban nem azt jelenti, hogy önmagában felelős lenne az összes olvasási zavarért. Ahogyan Ellis (2004) rámutat, a planum temporalék aszimmetriájának hiánya nem diszlexiásoknál is 
előfordul, másfelől pedig a fejlődési diszlexia különböző típusaiban feltehetőleg nem ugyanazok a neurológiai eltérések mutathatók ki.

Hemispherectomián átesett vagy hasított agyú betegekkel végzett vizsgálatok (Gazzaniga, 1983, Zaidel, 1985, Code, 1987, Ogden, 1996) azt bizonyították, hogy a szubdomináns félteke is számos nyelvi készség végrehajtásában vesz részt, bár korlátozott mértékben (Weekes és tsai, 1997). Ezen nyelvi készségek közé tartoznak a beszédprodukció (Code, 1996, 1997), az írott nyelvi produkció (Weekes, 1995), a szintaktikai végrehajtó funkciók (Dennis és Kohn, 1975, Smith és Sugar, 1975) és az írott szó felismerése (Weekes, 1995). Ebből következik, hogy a jobb illetve a bal agyfélteke sérülése egyaránt eredményezheti az írott nyelv megértésének nehezítettségét (Cherney, 2004, Swanberg és tsai, 2007, Ellis, 2004). Kutatások eredményei szerint a szubdomináns félteke sérülése esetén leginkább a vizuális feldolgozás folyamatának zavara befolyásolhatja az olvasási teljesítményt, ha azonban az agyi sérülés a domináns féltekét éri, az nyelvi deficitekkel járhat, mely érintheti az írott és verbális nyelvet együtt vagy külön-külön (Osmanné, 1997, Cherney, 2004, Ellis, 2004).

Bár ezek a hagyományos, neuroanatómiai alapú megkülönböztetések közelebb visznek bennünket a szerzett diszlexiák természetéhez, jelen tudásunk alapján nem adnak magyarázatot a páciensek rendkívül széles skálájára, így nem alkalmasak a terápia megtervezésére. Éppen ezért a szerzett olvasási zavarokkal kapcsolatban az érdeklődés fókusza mára áttevődött az anatómiai korrelációk vizsgálatáról a neurolingvisztikai és kognitív folyamatok vizsgálatára (Cherney 2004).

„A kognitív pszichológia, amely a normális mentális folyamatokat [...] tanulmányozza, ezen a ponton találkozott a neuropszichológiával, amely az emberi aggyal és annak funkciójával foglalkozik. A kettő együtt alkotja a kognitív neuropszichológiát, amely a kognitív funkciók agysérülés következtében megjelenő zavarait kutatja. Amikor a kognitív neuropszichológusok a szerzett diszlexiát vizsgálják, nem feltétlenül arra kíváncsiak, hogy a bizonyos olvasási zavart mutató betegek agyának melyik része sérült, hanem arra, hogy a normális olvasási folyamat melyik része vagy részei sérültek, illetve vesztek el teljesen. Az olvasási zavarok különböző mintáit tehát [...] a normális, rutinos szófelismerés modelljei alapján akarják megmagyarázni." (Ellis, 2004, 59-60. o.) A diszlexia kognitív neuropszichológiai vizsgálatának célja tehát, hogy az olvasási zavar altípusaira magyarázatokat adjon a normális olvasási folyamat sérült és többé-kevésbé ép folyamatainak meghatározásával. Ez az új megközelítés az 1970-es évektől kezd terjedni, és mára az olvasás és írás vizsgálatának alapját adja az agyi képalkotó eljárások eredményeivel kiegészítve (Ellis, 2004, Beeson és Rapcsak, 2006, Osmanné, 1997, Cherney, 2004, Csépe, 2006).

A kognitív folyamatok magasabb rendü pszichikus rendszerek, melyek „olyan alrendszerekből, >modulokból< állnak, amelyek egymástól viszonylag függetlenül müködnek, és az agy különböző lézióinál szelektíven károsodhatnak. Ezt nevezik $>$ frakcionálási feltevésnek $<$. Csak azoknak a feladatoknak a végrehajtása válik a beteg számára nehézzé vagy lehetetlenné, amelyekben a károsodott modul lényeges szerepet játszik. A beteg teljesíteni képes minden olyan feladatot, amely nem igényli e modul részvételét." (Osmanné, 1997, 52. o.) Vagyis bármely szerzett diszlexiában az olvasásban megjelenő tünetek a „normál olvasási rendszer” sérüléséből következnek (Weekes és tsai, 1997).

Az olvasás folyamatának modulokra bontására különböző modellek születtek, melyek alapján a szerzett diszlexia különböző típusai meghatározhatóvá válnak. 


\section{Ellis és Young egyesített szófelismerési modellje}

Az olvasási folyamattal kapcsolatos kérdéseket Pollatsek és Rayner (1989) tíz központi kérdésben foglalták össze a kognitív neuropszichológia nézőpontja alapján. Arra keresték a választ, hogy

1. hogyan ismeri fel az olvasó az írott szavakat;

2. a beszélt nyelvi rendszer milyen kapcsolatban van az olvasás nyelvi rendszerével;

3. miként befolyásolja a szövegkörnyezet az egyes szavak érzékelését;

4. az olvasás során a szemmozgások hogyan segítenek megértenünk az olvasás folyamatát;

5. hogyan fér hozzá az olvasó a szavak jelentéséhez (például hogyan elemzi az olvasó a mondatokat, a nyelvtanilag szerkesztett mondat jelentéséhez miként fér hozzá, hogyan képes az ismétlődő egységeket azonosítani, hogyan képes következtetéseket levonni, és így tovább);

6. mit tekinthetünk az olvasás végtermékének;

7. hogyan fejlődik az olvasási készség;

8. hogyan határozhatók meg az egyének közötti különbségek azonos, illetve különböző kulturális háttér esetén;

9. hogyan határozhatók meg és kezelhetők az olvasási nehézségek;

10. valamint hogy fejleszthető-e, és ha igen, miként a „normál olvasás” (lehetséges-e a „gyorsolvasás")?

A fenti tíz kérdés több mint húsz év távlatából nézve is megtartotta aktualitását, és a mai kognitív tudományok kutatásainak kulcskérdései maradtak (Rayner és Reichle, 2010). Ez idő alatt számos elmélet született az olvasás folyamatának leírására, de máig sem létezik olyan teória, mely az olvasási folyamat minden egyes összetevőjét tartalmazná. Modellek születtek a szavak azonosítására, a szintaxis elemzésére, a reprezentációk leírására, a nyelv különböző aspektusainak más folyamatokkal párhuzamba állítására, illetve a szemmozgások követésére. Sajnálatos módon azonban ezek a modellek ritkán kerültek egymással kölcsönhatásba a vizsgálatok során (Reilly és Radach, 2006).

Mivel a tanulmányban bemutatandó olvasásvizsgáló eljárásunk az Ellis és Young-féle egyesitett szófelismerési modellen alapul (Ellis, 2004), ezért itt csak ennek ismertetésére szorítkozunk. „A szófelismerés modelljei azokat a mentális folyamatokat kísérlik meg jellemezni, melyek lehetővé teszik az olvasó számára az írott szavak azonosítását, megértését és kiejtését. Megpróbálják elemeire bontani a szóazonosítás aktusát és leírni a komponensek müködését." (Ellis, 2004, 43. o.) Többen megkérdőjelezik, hogy lehet-e egy szófelismerési modellt az olvasás teljes folyamatára vonatkoztatni, a modellek szerzői azonban gyakran ezt teszik, s mi is eszerint járunk el.

Számos modell született ennek a folyamatnak a leírására, így például Morton logogén modellje (Morton, 1964), McClelland és Rumelhart (1981) interakciós-aktivációs modellje, Paap és tsai (1982) aktiváció-jóváhagyás modellje, Norris (1994) többszintű modellje, Grainger és Jacobs (1996) többszintü hangos olvasás modellje (Multiple Read-Out), Ans, Carbonnel és Valdois (1998) többnyomos memória modellje (Multiple-Trace Memory), Zorzi, Houghton és Butterwoth (1998) konnekcionista dupla feldolgozás modellje, a kétutas modellek (Coltheart és tsai, 2001, Carr és Pollatsek, 1985), Norris (2006) Bayes-féle olvasás modellje, valamint az ún. háromszög modellek csoportjába tarozó modellek (Seidenberg és McClelland, 1989, Plaut és tsai, 1996, Harm és Seidenberg, 1999, 2004).

Az egyesített szófelismerési modell (Ellis, 2004) a szófelismeréssel kapcsolatos elméletek főbb vonásait foglalja össze. Az írott szavak felismerésében szerepet játszó kognitív folyamatok leegyszerüsített, funkcionális modellje az 1. ábrán látható. 
1. ábra: A különálló írott szavak felismerésében szerepet játszó kognitív folyamatok leegyszerüsitett funkcionális modellje (forrás: Ellis, 2004, 45. o.)

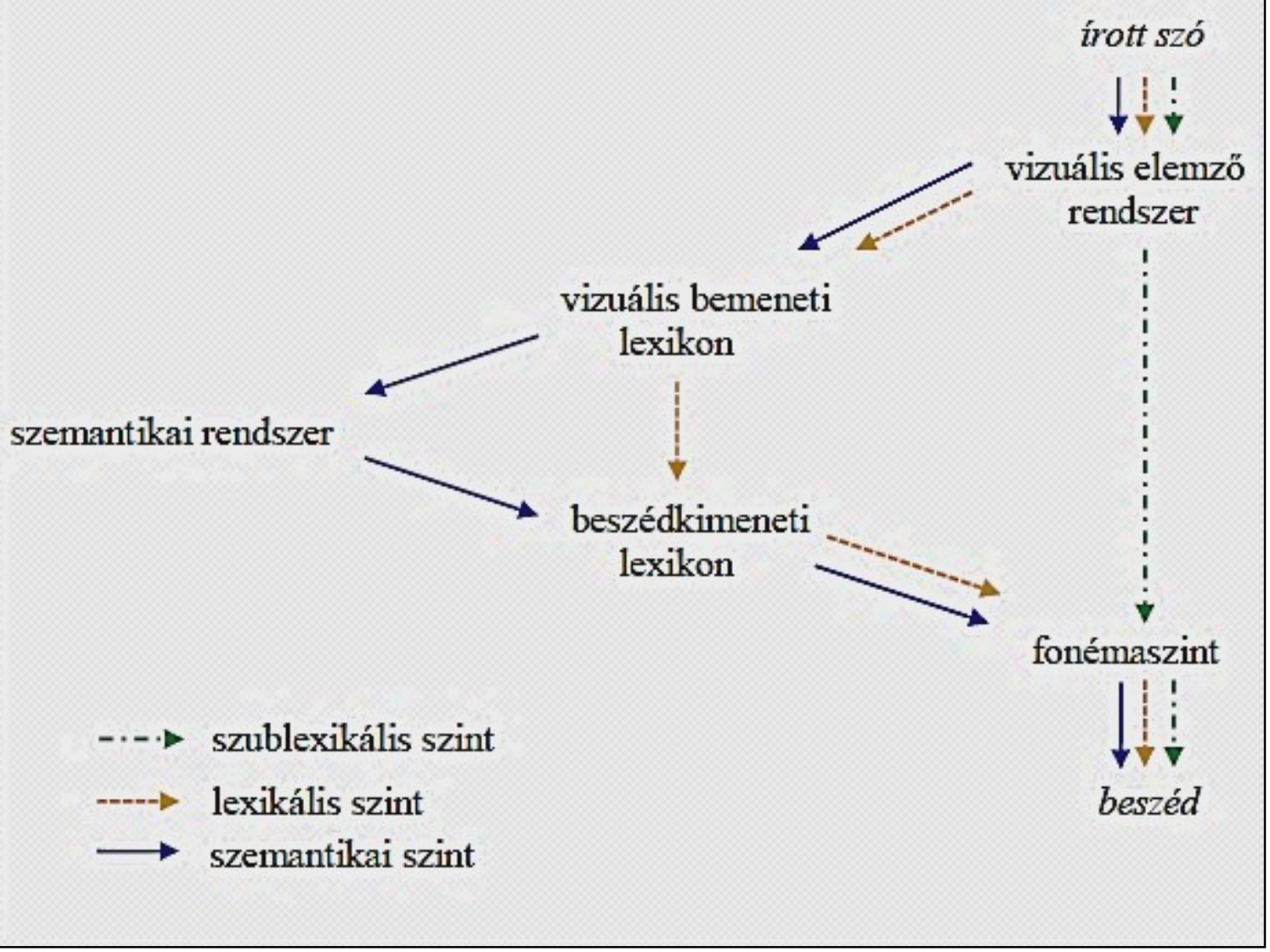

Az írott szó feldolgozásában az első részt vevő modul a vizuális elemzö rendszer, melynek kimenetei az elvont betűidentitások. Ezek „olyan reprezentációk, melyek elkülönítik az egyes betűket egymástól, de figyelmen kívül hagyják a betűk által felvehető esetleges alakokat" (Ellis, 2004. 44. o.). A vizuális elemző rendszernek ezekhez az elvont betűidentitásokhoz kapcsolódó feladata a betűk szóbeli pozícióinak meghatározása, mely lehetővé teszi azt, hogy a más-más sorrendben álló egyforma betűkből álló szavakat az olvasás során megkülönböztessük egymástól.

A vizuális elemző rendszer attól függetlenül müködik, hogy a stimulus létező szó vagy pedig álszó. A betüsorok ismert szóként való azonosítása a vizuális bemeneti lexikon modulban történik. „Ez egyfajta mentális szótár, amely az összes, az egyén által ismert szó grafikus alakjának reprezentációját tartalmazza. [...] A vizuális bemeneti lexikonból elérhetők a szavak jelentései és kiejtési mintái, de a vizuális bemeneti lexikon maga nem tartalmaz sem jelentéseket, sem kiejtési mintákat." (Ellis, 2004, 46. o.) A modell indikálja, hogy az olvasástanulás fontos lépéseként a vizuális bemeneti lexikonba a szavaknak megfelelö új grafikus egységek épülnek be, egyúttal ezekhez az egységekhez kimenetekként jelentések és kiejtési mintázatok kapcsolódnak.

Ebből következően vizuális bemeneti lexikon kimenete kétfelé ágazik. A beszédkimeneti lexikon a szavak kiejtési mintáit tartalmazza, míg a szemantikai rendszer nevü modul az olvasott szavak jelentéseivel való kapcsolatot adja meg. A jelentés elérése után azonban a felismerési folyamat ugyancsak a beszédkimeneti lexikonban folytatódik.

Amikor a fent leírt olvasási utak eredményeként hozzáfér az olvasó a beszédkimeneti mintákhoz, a minták a fonémaszint nevü tárba érkeznek, feltehetőleg fonémák soraként. Itt a 
hangok reprezentációi átalakulnak beszédmotoros mozgássorokká. A feladat végrehajtásához „fel kell tételeznünk egyfajta rövid távú emlékezeti tárat, amelyben a fonémák megőrződnek a felidézés és a kiejtés közötti időszakban." (Ellis, 2004, 51. o.) A tár létezését a szemmozgást olvasás közben vizsgálók is alátámasztották. Hangos olvasásnál ugyanis azt látjuk, hogy a legtöbbször a kiejtett szó előtt halad a tekintet. A fixált és az éppen kimondott részek közötti eltérés pedig a szem-hang intervallum (Levin, 1979).

Aszerint, hogy az olvasott egységek azonosításában mely modulok vesznek részt, a modell három olvasási utat különít el (1. ábra). Ha az azonosítás az irott szó $\rightarrow$ vizuális elemzö rendszer $\rightarrow$ fonémaszint $\rightarrow$ beszéd úton megy végbe, s így sem az egészleges szóformát, sem a jelentést nem érinti, szublexikális szintü olvasásról beszélünk. Ezt az olvasási utat használja az olvasni tanuló gyermek, de így olvasunk például álszavakat is, vagy amikor ismeretlen nyelven betüsorokat kell azonosítanunk.

Ha a folyamat érinti a vizuális bemeneti lexikont és a beszédkimeneti lexikont az írott szó $\rightarrow$ vizuális elemzö rendszer $\rightarrow$ vizuális bemeneti lexikon $\rightarrow$ beszédkimeneti lexikon $\rightarrow$ fonémaszint $\rightarrow$ beszéd útvonalon haladva, akkor az olvasás a lexikális szinten, az egészleges szavak szintjén történik. Ezt az olvasási utat akkor követjük, ha például az a feladat, hogy izolált szavak sorát olvassuk fel minél gyorsabban.

Amikor a vizuális szófelismerésbe a jelentés is bekapcsolódik az irott szó $\rightarrow$ vizuális elemzö rendszer $\rightarrow$ vizuális bemeneti lexikon $\rightarrow$ szemantikai rendszer $\rightarrow$ beszédkimeneti lexikon $\rightarrow$ fonémaszint $\rightarrow$ beszéd modulok útján, akkor szemantikai szintü olvasásról van szó. Ezt az utat használjuk rutinos olvasóként az összefüggő szövegek olvasása során, és ez teszi lehetővé a hangos olvasásban a megfelelö hangsúlyozást is. Ilyen esetben az olvasott szavak jelentése aktiválódik a szemantikai rendszerben, mielőtt a beszédkimeneti lexikonban hozzáférhetővé válnának a kiejtési minták.

Tanulmányunk további részében a szerzett olvasási zavart az egyesített szófelismerési modell keretében értelmezzük, valamint ez a modell képezi olvasásvizsgáló eljárásunk alapját is. Ehhez azonban egy kritikai korrekcióval kell élnünk: Ellis (2004) megfogalmazásában a vizuális bemeneti lexikon egy mentális szótár, mely az egyén által ismert szavak grafikus mintázatát tartalmazza, miközben nem tartalmaz jelentéseket. Véleményünk szerint a gondolatmenet önmagában ellentmondást hordoz, ha ugyanis egy ismert szó grafikus alakját látjuk, tulajdonképpen elképzelhetetlen olyan spontán vagy mesterséges (kísérleti) szituáció, hogy a szó jelentése (azonnal) ne aktiválódjon elménkben. Az Ellis-i modellt szigorúan értelmezve tehát a lexikális olvasási szint nem létezik. Azt gondoljuk azonban, hogy a lexikális szint elkülönítésének jogosultsága van, mégpedig oly módon, hogy szó szintü olvasásról akkor beszélünk, amikor - mint az fentebb írtuk - különálló, kontextus nélküli szavakat olvasunk fel. A szemantikai szintü olvasás pedig azt jelenti, hogy kontextusba kerülve a szó szemantikai és szintaktikai pozíciója révén (ezáltal facilitálva) aktiválódik az aktuális jelentés.

\section{A szerzett olvasási zavar az egyesített szófelismerési modell tükrében}

Súlyosabb afáziás kórformáknál az olvasás és az írás képessége teljesen elvész. Amint a nyelvi zavar enyhül, esetenként az írásbeli kommunikációs készség is javulást mutat, de a klinikai tapasztalat az, hogy fejlesztő beavatkozás nélkül a beteg csak néhány szó „kiolvasására”, azaz szóképként való azonosítására lesz képes. Ugyanis sok esetben károsodott a beszédhangok mentális reprezentációja, valamint a betü-hang kapcsolatok létrehozásának a képessége, $\mathrm{s}$ az afáziás személy csak a vizuális bemeneti lexikonban megmaradt képeket ismeri fel, kimondani pedig csak azokat tudja, melyekhez a beszédkimeneti lexikonban fonológiai minta érhető el, tehát számára csak a lexikális olvasási út járható (Ellis, 2004). Vagyis megszünik az olvasás szublexikális útja, ismeretlen szavak kiolvasása például egyáltalán nem lehetséges, és a toldalékolt szóalakok azonosítása is 
nehézséget okoz, mivel a szó hangszerkezetébe behatolni nem képes a beteg. Viszont a nyelvi és nem nyelvi funkciók, így többek között a mentális lexikon, a grammatikai és szemantikai tudatosság, a verbális munkaemlékezet, a központi végrehajtó müködés (Baddeley, 2003, Racsmány, 2004), a vizuális szeriális észlelés, az analízis-szintézis, a figyelem zavara miatt a rutinos olvasókra jellemző szemantikus út sem járható (Tóth, 2002, Ellis, 2004, Csépe, 2006). Vagyis az afáziás személy nem képes arra, hogy a lexikális szint fölött, a mondat szintaktikai szerkezetének és szemantikai kontextusának segítö hatását kihasználva gördülékenyen, az olvasott szöveget meg is értve olvasson (Helm-Estabrooks és tsai, 2004).

\section{A SZERZETT OLVASÁSI ZAVAR VIZSGÁLATA}

„Ahhoz hogy az ember a különbözö organikus agykárosodott betegek kognitív- és viselkedésdeficitjeinek kezelésében eredményesen müködhessen, elengedhetetlen a széles körü diagnosztikus tapasztalat. Épp így nélkülözhetetlen, hogy a funkciódeficitek vizsgálata közben kitekintést nyerjünk az épen maradt pszichés funkciókra.” (Pataky, 2005, 122. o.)

Angol nyelven az olvasás vizsgálatára számos eljárás létezik. A tesztek általában hierarchikus rendezettséget követnek, kezdve a betük olvasásától, az egyszavas feladatokon, majd mondatokon át egészen a bekezdés szintjéig (Cherney, 2004). Angol nyelven elérhetö, kifejezetten az olvasás értését vizsgáló eljárások a Reading Comprehension Battery for Aphasia (Második kiadás) (RCBA-2) (LaPointe és Horner, 1998), a Gates-MacGinitie Reading Tests (MacGinitie és tsai, 2000), a Woodcock Reading Mastery Tests (Woodcock, 1998), a Nelson-Denny Reading Tests (Brown és tsai, 1993), a Psycholinguistic Assessments of Language Processing in Aphasia (PALPA) (Kay és tsai, 1992), a The Johns Hopkins University Dyslexia Battery (Goodman és Caramazza, 1986), a Battery of Adult Reading Functions (Coslett, 1985), valamint a The Grey Oral Reading Test - 4 (GORT - 4) (Wiederholt és Bryant, 2001).

A fentieken kívül az általános afáziavizsgálatok is rendelkeznek olvasást vizsgáló szubteszttel, bár ezek nem annyira részletesek és érzékenyek, mint a fenti eljárások (Kertesz, 1982, Goodglass és tsai, 2000). Magyar nyelven ez idáig az egyetlen szabadon hozzáférhető vizsgálóeljárás a Western Aphasia Battery olvasási képességet mérő altesztje (Kertesz, 1982).

\section{A Western Aphasia Battery olvasást vizsgáló szubtesztje}

A Western Aphasia Battery (WAB) olvasást vizsgáló altesztje (1. 1. melléklet) a mondat, a szó és a betü/hang szintjén méri az olvasási képességet, s kritikusai szerint az egyes szintekhez tartozó példák alacsony száma miatt szürőeljárásként alkalmazható (Cherney, 2004, Friedman, 2002). Magyarországon egyeduralkodó olvasásvizsgáló tesztként terjedt el.

A teszt első két feladata olvasott mondatok megértését vizsgálja. Az A. feladat egyre hosszabb terjedelmü mondatok, mondatsorok kiegészítését várja el egy-egy kiválasztott szóval. A B. feladat egyre bonyolultabb utasítások végrehajtását kéri. Az instrukció szerint, ha ebben a két feladatban összesen legalább 83,3\%-os a teljesítmény, akkor a vizsgálatot nem szükséges folytatni. A magyar nyelvü változat megjegyzi azonban, hogy lehetséges, hogy a beteg szóképolvasó, aminek a lehetőségét a teszt további feladatainak elvégeztetésével zárhatjuk ki. (Erre az angol nyelvü változatban nem találunk utalást.)

A C-F. feladatok az olvasást a szavak szintjén vizsgálják, rendre szókép-tárgy, szóképtárgykép, tárgykép-szókép illetve hangalak-szókép azonosítás által. A C-E., vizuális szófelismerés feladatokban az a hat fónév (tárgyak és a tárgyképek) alkalmazandó, amelyek a WAB általános részében is szerepelnek, mindegyikük nagy gyakoriságú főnév, az élet korai szakaszában elsajátítottak, terjedelmüket tekintve pedig alacsony szótagszámúak. Az F., auditív szófelismerés feladatban a célszónak megfelelő szókép mellett szerepel 2 fonetikailag 
illetve 2 szemantikailag hasonló szó képe. Az értékelésnél fontos, hogy mely nyelvi szinten történik tévesztés.

A G. feladat fonéma-graféma konverziót, azaz nyomtatott nagybetük azonosítását várja el, A H. és J. feladatban pedig fonológiai manipulációt (szintézist illetve analízist) kérünk a betegtől.

Az A., B., H. és J. feladatok verbális, míg a C., D., E., F. és G. feladatok non-verbális válaszadást kívánnak.

Ellis modellje alapján a feladatok a következőképp csoportosíthatók: a szublexikális utat vizsgálja a G., H. és J. feladat, egyenként hat példával; a lexikális utat vizsgálja a C., D., E., és F. feladat, hat-hat-hat-négy példával, a szemantikai utat pedig az A. és B. feladatok nyolc, illetve hat példával.

Az eljárás alkalmazása során az alábbi kritikát fogalmaztuk meg:

Az eljárás nem sztenderdizált, a Logopédiai vizsgálatok kézikönyve (Juhász 2007) nem tartalmazza, az interneten egy logopédus honlapjáról tölthető le (Net.1). Használatához a betegnek adandó instrukciókon kívül semmiféle útmutató nem áll rendelkezésre magyar nyelven. Ezek nem törekszenek az angol nyelvü vizsgálatban adott leírások pontos és teljes fordítására, ami a vizsgálati eredményeket is befolyásolhatja. Az ehhez tartozó szókártyák sem követik a WAB angol nyelvü változatában meghatározott szabványt: általában a logopédustól függ, hogy milyen betüméretet és betütípust választ.

A betegnek adandó utasítások sem mindig egyértelmüek: nem derül ki, hogy hangosan vagy némán kell-e olvasnia.

A verbális válaszadást elváró feladatok esetében nem lehet eldönteni, hogy a beszédprodukció vagy az olvasás zavara áll-e a háttérben (vagy mindkettö).

Nyelvi szintenként illetve feladatonként a következő problémákat tapasztaltuk:

A mondat szintjét vizsgáló feladatok nagymértékben igénybe veszik a verbális munkaemlékezetet, ami afáziás személyeknél általában jelentősen csökkent kapacitással müködik. A növekvő hosszúságú illetve nyelvtani bonyolultságú itemekre adott helyes válaszok egyre több pontot érnek, így gyenge munkamemória esetén az olvasási teljesítményt is gyengébbnek értékeljük. Továbbá az A. feladatban egyes itemeknél a helyes válaszhoz lexikális és grammatikalitási döntés együttesen szükséges, így nem feltétlenül az olvasási képességet mérjük, más itemeknél pedig több választás is helyes megoldást eredményez, ami növeli a találgatás esélyét és bizonytalanná teszi az értékelést.

A szó szintjét vizsgáló feladatok közül három ugyanazzal a hat fogalommal dolgoznak, így adott esetben a tanulási hatás befolyásolhatja az eredményeket.

A H. és J. feladatok nem az olvasást, hanem a fonológiai tudatosságot, ezen belül a szintézis és analízis képességét vizsgálják.

Az eredeti közlemény gépelési, helyesírási hibákat tartalmazott, önmagában a vizsgálat lefolytatására alkalmatlan volt, ezért saját használatra formailag átalakítottuk.

\section{A Háromutas Olvasásvizsgáló Teszt}

A fenti módszertani hibák elkerülése végett olvasásvizsgáló eljárásunkat úgy készítettük el, hogy a következő kritériumokat teljesítse:

a) A módszertani utasítások, a pontozás és az értékelés a vizsgálatvezető számára egyértelmü.

b) A betegnek szóló instrukciók egyszerüek és rövidek.

c) Feladatonként csak egy helyes válasz van.

d) A feladatok anyaga általános ismeretekre támaszkodik.

e) A szó-, tárgy-, és eseményképek, mondatkártyák mérete, vizuális megjelenítése a stroke-on átesett személyek szükségleteihez alkalmazkodik.

f) Cél, hogy az olvasási képesség expresszív beszédzavar esetén is felmérhető legyen. 
Feladat a hangos olvasás, de ahol csak lehet, non-verbális válaszadás is elfogadott. A legtöbb feladatban képeket használunk az ellenőrzéshez.

g) Az olvasási teljesítmény szintenként elkülönített mérése lehetővé teszi a terápiás folyamat tervezését.

Az Ellis és Young-féle egyesitett szófelismerési modellen (Ellis, 2004) alapuló eljárásunk az olvasási képességet tehát a szublexikális, a lexikális és a szemantikai olvasási úton vizsgálja. A vizsgálat verbális anyagát az instrukciókkal a 2. melléklet tartalmazza.

I. A szublexikális szint 5 feladatot tartalmaz. Az 1. feladat kivételével ezen a szinten verbális válaszadást várunk el. Az 1-3. feladat kizárólag a szó szintje alatti olvasási folyamatokat vár el 24-24 itemmel fonéma-graféma illetve graféma-fonéma konverziós mủveletek, valamint 16 itemmel grafémák összeolvasása (álszóolvasás egyre növekvő szótagszámmal) révén. A 4. és 5. feladat azonban tudatosan ,átlát” a lexikális olvasási útra is, miszerint a betüáthelyezéses szavak - 15 itemmel, egyre növekvő szótagszámmal -, majd a valódi szavak - 20 itemmel, egyre növekvő szótagszámmal - olvasása során nyújtott teljesítmény mintázatában, időeredményében információval szolgál arra nézvést, hogy a beteg szublexikális vagy a lexikális szinten olvas-e. Ha ugyanis a betủáthelyezéses szavak helyett az eredeti valódi szavakat olvassa ki (például a hedegül célszó helyett a válasz hegedül), az azt jelenti, hogy a szó szintje alatti szeriális rendezés müvelete nem müködik. Abból, ha a valódi szavakat helyesen és rutinos olvasónak megfelelő tempóban olvassa ki a vizsgált személy, az természetesen nem következik, hogy a szublexikális folyamatok ne müködnének, ha viszont e feladatban sok a tévesztés vagy lassú az olvasás tempója, valószínü, hogy a lexikális szinten van a probléma.

II. A lexikális szint mérése a 6. feladatban tárgykép-szókép egyeztető egységekkel történik az olvasás mellett a non-verbális válaszadást is értékelve. A feladat a) részében a vizsgálat alanyának négy bemutatott szókép közül a megfelelöhöz kell egy adott tárgyképet illesztenie, a b) részben pedig négy bemutatott tárgykép közül kell kiválasztania azt, amelyik egy adott szóképnek megfelel. Mindkét részfeladatban rendre főneveket, igéket majd mellékneveket jelentő fogalmakat használtunk 3-3 itemmel. Minden esetben a célszón kívül a lehetséges válaszok között szerepel egy a célszóhoz fonológiailag hasonló, egy szemantikailag hasonló és egy semmilyen asszociációval nem rendelkező fogalom.

III. A szemantikai szint két feladatot tartalmaz, az olvasás mellett a non-verbális válaszadást is értékeljük. A 7. feladat a) részében egy mondatkártyát kell illeszteni négy eseménykép közül a megfelelöhöz, a b) részben egy eseményképhez kell megtalálni az eseményt leíró mondatkártyát. A feladatokba ún. disztraktorokat iktattunk be: az a) feladatsorba a célképen kívül minden item tartalmaz egy a célmondat alanyával, egy az állítmányi résszel asszociálható, illetve egy asszociatív kapcsolatban nem lévő eseményképet. A b) feladatsor mondatkártyái közül egy a célmondatot tartalmazza. Ezen kívül beépítettünk a válaszlehetőségek közé egy olyan mondatot, melyben a thematikus szereplőket megcseréltük, ezáltal aszemantikus mondatot kaptunk. A harmadik mondat azonos szereplőkkel, más állítmánnyal szemantikailag (és grammatikailag) helyes mondat, a negyedik mondat pedig semmilyen módon nem hasonlít a célmondatra. Mindkét részfeladat 4-4 itemet tartalmaz. Az utolsó, 8. feladatban 5 közmondással dolgozunk: Eseményképeket, valamint a közmondásokat és a közmondások jelentését tartalmazó mondatkártyákat kell egymáshoz rendelni. A kliensnek először ki kell választania, melyik eseményképhez melyik közmondás tartozik, majd meg kell találni az egyes közmondásokhoz a jelentésüket.

A vizsgálatban minden egyes itemre adott helyes válaszért 1 pontot adunk. A lexikális és a szemantikai szint feladataiban a helyesen olvasott itemekért újabb 1-1 pont jár. (Ha a beteg adott feladatban kimondja a helyes megoldást, de hibásan választja ki a szóképet vagy a mondatkártyát, azt följegyezzük, de pontot nem adunk rá.) Az olvasási időt a szublexikális szinten az 1-2. feladatban a feladatonként mérjük, a 3-5. feladatban pedig az adott 
szótagszámú itemek elolvasásával töltött időtartamokat mérjük meg. A lexikális olvasási út idejét úgy mérjük, hogy az egyes szófajokhoz tartozó 3-3 item megoldásával töltött időt egybe számítjuk, a szemantikai út esetében pedig az egyes mondatok kiolvasásának idejét mérjük meg.

Mivel az eljárást egyelőre csak kis számú afáziás kliens esetében teszteltük, elsősorban a WAB olvasásvizsgáló eljárással való összehasonlítás céljából, valamint ép nyelvi és olvasási képességgel bíró személyek tesztelése jelenleg folyik, ponthatárokat ez idáig nem állapítottunk meg, s a mért olvasási időket nem használtuk fel az értékelésnél. Jelen tanulmányban tehát csak a két eljárás összevetéséböl szerzett tapasztalatainkról fogunk beszámolni.

\section{A HOT és a WAB olvasásvizsgáló eljárás összevetésének tapasztalatai}

A két táblázat felépítését az 1. táblázatban foglaltuk össze. A vizsgálóeljárások hasonló struktúra mentén épülnek fel, de véleményünk szerint HOT az olvasási utak tekintetében kiegyenlítettebb szerkesztésü, valamint feladatai relevánsabbak, az adott olvasási úton a mérési célnak jobban megfelelnek, másrészt a nyelvi anyagukban változatosabbak, mint a WAB olvasásvizsgáló eljárás.

\section{1. táblázat: $A$ WAB és a HOT olvasásvizsgáló eljárás feladatainak rendszerezése}

\begin{tabular}{|c|c|c|}
\hline & WAB-olvasás & HOT \\
\hline \multirow{3}{*}{$\begin{array}{c}\text { Szublexikális } \\
\text { út }\end{array}$} & $\begin{array}{l}\text { Betüdiszkrimináció (fonéma-graféma } \\
\text { konverzió) }\end{array}$ & $\begin{array}{l}\text { Graféma-fonéma } \\
\text { (betűdiszkrimináció) }\end{array}$ \\
\hline & $\begin{array}{l}\text { Betüzés alapján szófelismerés } \\
\text { (auditív fonémaszintézis }- \text { nem } \\
\text { olvasás!) }\end{array}$ & $\begin{array}{l}\text { Fonéma-graféma konverzió (betük } \\
\text { megnevezése) }\end{array}$ \\
\hline & $\begin{array}{l}\text { Betüzés (auditív fonéma-analízis - } \\
\text { nem olvasás!) }\end{array}$ & Álszavak olvasása \\
\hline \multirow{4}{*}{ Lexikális út } & $\begin{array}{l}\text { Írott szó alapján tárgy kiválasztása } \\
\text { (szókép-tárgy egyeztetés) }\end{array}$ & Betüáthelyezéses szavak olvasása \\
\hline & $\begin{array}{l}\text { Írott szó alapján kép kiválasztása } \\
\text { (szókép-tárgykép egyeztetés) }\end{array}$ & Valódi szavak olvasása \\
\hline & $\begin{array}{l}\text { Kép alapján írott szó kiválasztása } \\
\text { (tárgykép-szókép egyeztetés) }\end{array}$ & $\begin{array}{l}1 \text { tárgykép }-4 \text { szókép (tárgykép- } \\
\text { szókép egyeztetés) }\end{array}$ \\
\hline & $\begin{array}{l}\text { Kiejtett szó - írott szó összevetése } \\
\text { (hangsor-szókép egyeztetés) }\end{array}$ & $\begin{array}{l}4 \text { tárgykép - } 1 \text { szókép } \\
\text { (szókép-tárgykép egyeztetés) }\end{array}$ \\
\hline \multirow{4}{*}{$\begin{array}{c}\text { Szemantikai } \\
\dot{u} t\end{array}$} & $\begin{array}{l}\text { Olvasott mondatok megértése, } \\
\text { befejezése }\end{array}$ & $\begin{array}{l}1 \text { mondat }-4 \text { kép (mondat- } \\
\text { eseménykép egyeztetés) }\end{array}$ \\
\hline & Utasítások olvasása, végrehajtása & $\begin{array}{l}4 \text { mondat }-1 \text { kép (eseménykép- } \\
\text { mondat egyeztetés) }\end{array}$ \\
\hline & & $\begin{array}{l}\text { Képekhez közmondás illesztése } \\
\text { (eseménykép-mondat egyeztetés, } \\
\text { metaforikus nyelvhasználat) }\end{array}$ \\
\hline & & $\begin{array}{l}\text { Közmondásokhoz jelentés illesztése } \\
\text { (mondat-mondat } \\
\text { metaforikus nyelvhasználat) }\end{array}$ \\
\hline
\end{tabular}




\section{A kutatás célja}

Az eljárásokkal kapcsolatban feltételeztük, hogy

a) a két vizsgálóeljárás előkészítése, felvétele és értékelése adott beteg esetében nagyjából ugyanannyi időt vesz igénybe;

b) a HOT értékelése áttekinthetőbb, egyértelmübb, mint a WAB olvasásvizsgálatáé, ennél fogva

c) bár a két eljárás felvételével összességében hasonló eredményeket kapunk, HOT differenciáltabb képet ad az egyes olvasási utak funkcióképességéröl, mint a WAB, ezzel lehetővé teszi az olvasási zavar minőségének és mértékének meghatározását, ami támpontot nyújt a terápia megtervezéséhez kiegészítő vizsgálatok nélkül is.

\section{MÓDSZER}

\section{Minta}

A vizsgálatokban 7 , nonfluens, a WAB szóbeli vizsgálat alapján motoros túlsúlyú szenzomotoros afáziával diagnosztizált személy (5 nö, 2 férfi; 53-78 év között) vett részt. A vizsgálatok időpontjában mindnyájan az ESZSZK Rehabilitációs Centrumának kliensei, akik a centrumban töltött 3-4 hét alatt heti két alkalommal 60 perc logopédiai ellátásban részesültek. A betegek nyelvi státuszát a 2 . táblázat mutatja be.

2. táblázat: $A$ WAB és a HOT olvasásvizsgálatban résztvevö személyek nyelvi státusza a WAB szóbeli vizsgálat alapján

\begin{tabular}{c|c|c|c|}
\cline { 2 - 4 } beteg & $\begin{array}{c}\text { expresszív oldal } \\
\text { érintettsége }\end{array}$ & receptív oldal érintettsége & anómia \\
\hline $\mathbf{1 .}$ & $\begin{array}{c}\text { középsúlyos } \\
\text { (diszgrammatizmus) }\end{array}$ & $\begin{array}{c}\text { enyhe fokú (hosszabb, } \\
\text { bonyolultabb közlések } \\
\text { értése) }\end{array}$ & enyhe fokú \\
\hline $\mathbf{2 .}$ & $\begin{array}{c}\text { középsúlyos } \\
\text { (diszgrammatizmus) }\end{array}$ & $\begin{array}{c}\text { enyhe fokú (hosszabb, } \\
\text { bonyolultabb közlések } \\
\text { értése) }\end{array}$ & enyhe fokú \\
\hline $\mathbf{3 .}$ & súlyos (agrammatizmus) & középsúlyos & súlyos \\
\hline $\mathbf{4 .}$ & $\begin{array}{c}\text { súlyos (agrammatizmus } \\
\text { motoros beszédzavarral) }\end{array}$ & középsúlyos & enyhe fokú \\
\hline $\mathbf{5 .}$ & $\begin{array}{c}\text { enyhe } \\
\text { (diszgrammatizmus) }\end{array}$ & nem érintett \\
\hline $\mathbf{6 .}$ & $\begin{array}{c}\text { középsúlyos } \\
\text { (diszgrammatizmus) }\end{array}$ & $\begin{array}{c}\text { enyhe fokú (hosszabb, } \\
\text { bonyolultabb közlések } \\
\text { értése) }\end{array}$ & középsúlyos \\
\hline $\mathbf{7 .}$ & $\begin{array}{c}\text { nenyhe fokú } \\
\text { (maradványtünetek) }\end{array}$ & nérintett & enyhe fokú \\
\hline
\end{tabular}

\section{Anyag}

Vizsgálatainkban a WAB és a HOT olvasásvizsgáló eljárást vettük fel betegeinkkel. A két eljárást az előző fejezetekben részletesen bemutattuk, anyaguk az 1. és a 2 . mellékletben megtekinthetö.

\section{Elrendezés}

A felmérésekre az ESZSZK Rehabilitációs Centrum logopédiai kezelöjében került sor. A résztvevőkkel először a WAB olvasásvizsgálatot, majd a HOT eljárást vettük föl. A vizsgálatokat két egymást követő foglalkozás keretében végeztük el, így a két ülés között 3-4 nap telt el. 
A teszteket minden beteggel egyéni helyzetben vettük fel. A betegek válaszait a vizsgálat menetében papíron rögzítettük, illetve a felmérésröl diktafonnal felvételt készítettünk. Egyegy ülés kb. 20 percet vett igénybe, kivéve a 6 . betegnél, akinél 45 illetve 55 percig tartott a két mérés.

\section{Eredmények}

A két teszt eredményeit külön-külön mutatjuk be. Az alacsony elemszám miatt statisztikai elemzést nem végeztünk, az eredményeket betegenként nyerspontokban, majd százalékpontokban adjuk meg. Az olvasási időtartamokat egyik eljárás esetében jelenítettük meg.

\section{WAB olvasásvizsgálat}

A felmérés értékelésében az anyagban szereplő utasítás szerint jártunk el, ahol jó több megoldás is lehetséges volt (A. feladat), ott ezek bármelyikére megadtuk a megfelelő pontszámot. A 3. táblázat a teszt eredményeit nyerspontokban, a 4. táblázat pedig százalékpontokban mutatja. A WAB olvasásteszttel vizsgálva egyik résztvevő sem érte el a maximális pontszámot illetve a $100 \%$-ot, tehát a teszt minden betegünknél olvasászavart jelzett.

\section{3. táblázat: A WAB olvasásvizsgálat eredményei nyerspontokban}

\begin{tabular}{|c|c|c|c|c|c|c|c|c|c|c|c|}
\hline$\underset{\frac{5}{5}}{\frac{5}{2}}$ & 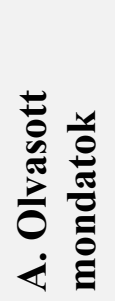 & 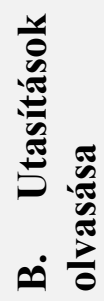 & 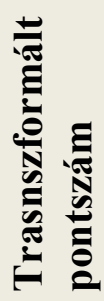 &  & 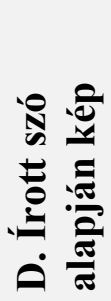 & 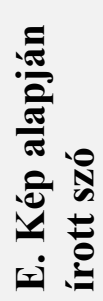 & 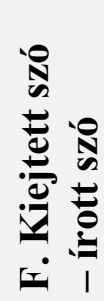 &  & 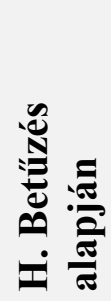 &  & 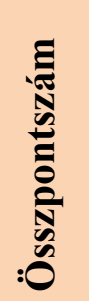 \\
\hline \multicolumn{12}{|l|}{$\begin{array}{l}\text { Bet } \\
\text { eg }\end{array}$} \\
\hline 1. & 34 & 15 & 78 & 6 & 6 & 6 & 4 & 6 & 2 & 1 & 80 \\
\hline 2. & 34 & 18 & 84 & 6 & 6 & 6 & 2 & 6 & 0 & 0 & 78 \\
\hline 3. & 28 & 18 & 72 & 6 & 6 & 6 & 4 & 6 & 5 & 1 & 80 \\
\hline 4. & 18 & 2 & 20 & 6 & 6 & 6 & 2 & 5 & 0 & 0 & 45 \\
\hline 5. & 40 & 13 & 86 & 6 & 6 & 6 & 3 & 6 & 2 & 1 & 83 \\
\hline 6. & 30 & 0 & 40 & 6 & 6 & 6 & 4 & 4 & 0 & 0 & 56 \\
\hline 7. & 36 & 16 & 84 & 6 & 6 & 6 & 3 & 6 & 5 & 5 & 89 \\
\hline $\begin{array}{l}\text { Ma } \\
x . \\
\text { pon } \\
t- \\
\text { szá } \\
m\end{array}$ & 40 & 20 & 100 & 6 & 6 & 6 & 4 & 6 & 6 & 6 & 100 \\
\hline
\end{tabular}

A 3. táblázatban az A. és B. feladatok után feltüntettük az utasítás szerint kiszámított transzformált pontszámot is. Ezt összevetve a további feladatokban - föként az F-J. feladatokban - nyújtott teljesítménnyel nyilvánvalóvá válik, hogy - legalábbis magyar nyelvterületen - akkor sem hagyható el a teszt további részének felvétele, ha a transzformált pontszám eléri az 50 pontot ( $83,3 \%$-ot). 
4. táblázat: A WAB olvasásvizsgálat eredményei százalékpontokban

\begin{tabular}{|c|c|c|c|c|c|c|c|c|c|c|c|c|c|}
\hline $\begin{array}{l}5 \\
5 \\
5 \\
0 \\
0\end{array}$ & 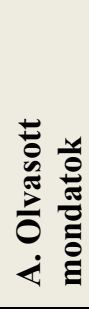 &  & 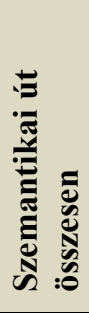 & 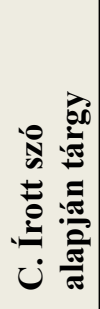 & 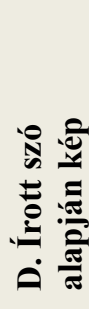 & 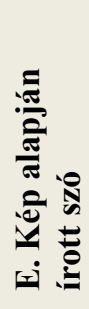 & 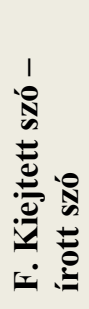 & & 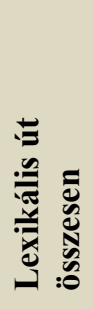 & 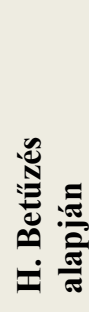 & 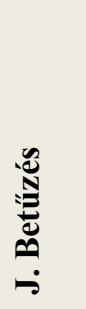 &  & 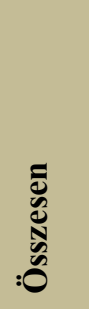 \\
\hline 1. & 85 & 75 & 81,7 & 100 & 100 & 100 & 100 & 100 & 100 & 33,3 & 16,7 & 50 & 77,2 \\
\hline 2. & 85 & 90 & 86,7 & 100 & 100 & 100 & 50 & 100 & 90,9 & 0 & 0 & 33,3 & 70,3 \\
\hline 3. & 70 & 90 & 76,7 & 100 & 100 & 100 & 100 & 100 & 100 & 83,3 & 16,7 & 66,7 & 81,1 \\
\hline 4. & 45 & 10 & 33,3 & 100 & 100 & 100 & 50 & 83,3 & 90,9 & 0 & 0 & 27,8 & 50,6 \\
\hline 5. & 100 & 65 & 88,3 & 100 & 100 & 100 & 75 & 100 & 95,5 & 33,3 & 16,7 & 50 & 77,9 \\
\hline 6. & 75 & 0 & 50 & 100 & 100 & 100 & 100 & 66,7 & 100 & 0 & 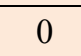 & 22,2 & 57,4 \\
\hline 7. & 90 & 80 & 86,7 & 100 & 100 & 100 & 75 & 100 & 95,5 & 83,3 & 83,3 & 88,9 & 90,4 \\
\hline
\end{tabular}

A 4. táblázat százalékos adataiból kitünik, hogy míg a szemantikai és a lexikális úthoz tartozó feladatokban az afáziás személyek viszonylag jól teljesítettek, addig a szublexikális út feladataiban többségük gyenge vagy igen gyenge eredményt ért el. Az, hogy három szint közül a lexikális feladatokban teljesítettek a legjobban igazolja, hogy szerzett olvasási zavar esetében valóban a szóképolvasás funkciója őrződik meg valamilyen mértékben. Azonban az eljárással mért olvasási teljesítmény nem minden esetben van összhangban a WAB szóbeli tesztjének megállapításaival (1. 2. táblázat).

\section{HOT eljárás}

A teszt pontozási rendszerét fentebb ismertettük. Az értékelésnél elsősorban az egyes olvasási szinteken elért eredményekre fektettük a hangsúlyt, mivel az összesített pontszámoknak valójában nincs jelentőségük. A 3-5. feladatokat a szublexikális úthoz soroltuk, átmeneti jellegüket jelen értékelésben nem vettük figyelembe. Továbbá nem jelenítjük meg azt, hogy - ahol nem volt feltétlenül szükséges - a feladatmegoldást kísérte-e hangos olvasás, s ennek minősége milyen volt. A felmérés eredményeit nyerspontokban az 5. táblázat tartalmazza.

\section{5. táblázat: A HOT olvasásvizsgálat eredményei nyerspontokban}

\begin{tabular}{|c|c|c|c|c|c|c|c|c|c|c|c|c|c|c|c|}
\hline $\begin{array}{l}\$ \\
\vdots \\
5 \\
0\end{array}$ &  & 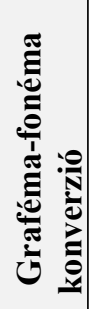 & 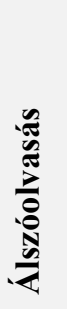 & 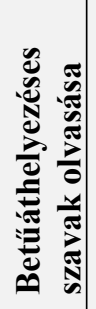 & 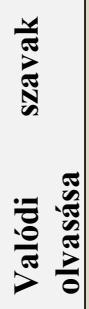 & 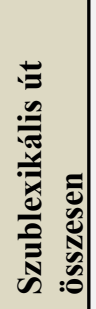 & 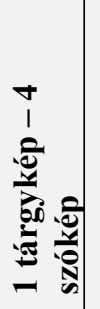 & 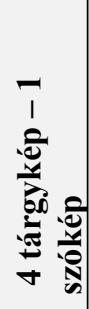 & 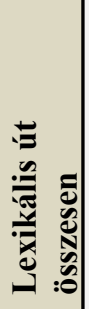 & 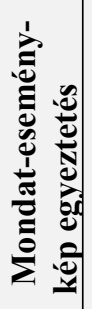 & 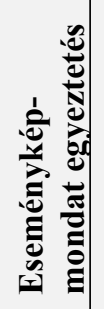 &  & 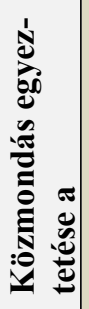 & 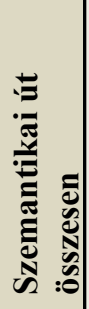 & 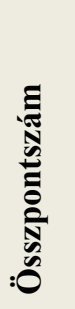 \\
\hline 1. & 21 & 24 & 12 & 8 & 20 & 85 & 18 & 18 & 36 & 6 & 8 & 10 & 6 & 30 & 151 \\
\hline 2. & 24 & 24 & 14 & 10 & 20 & 92 & 14 & 14 & 28 & 6 & 6 & 10 & 6 & 28 & 148 \\
\hline 3. & 23 & 23 & 5 & 2 & 20 & 73 & 18 & 18 & 36 & 8 & 6 & 10 & 4 & 28 & 137 \\
\hline 4. & 3 & 4 & 0 & 0 & 0 & 7 & 13 & 13 & 26 & 2 & 3 & 5 & 0 & 10 & 43 \\
\hline 5. & 11 & 23 & 5 & 2 & 19 & 60 & 18 & 18 & 36 & 6 & 8 & 10 & 10 & 34 & 130 \\
\hline 6. & 13 & 16 & 0 & 0 & 5 & 34 & 12 & 18 & 30 & 6 & 5 & 5 & 5 & 21 & 85 \\
\hline 7. & 24 & 24 & 15 & 10 & 20 & 93 & 16 & 18 & 34 & 8 & 8 & 10 & 6 & 32 & 159 \\
\hline$M$ & 24 & 24 & 16 & 15 & 20 & 99 & 18 & 18 & 36 & 8 & 8 & 10 & 10 & 36 & 171 \\
\hline
\end{tabular}


Mivel az egyes olvasási utakhoz eltérö összpontszámok tartoznak, az eredményeket a 6. táblázatban százalékpontokban is megadtuk. Ennek alapján megállapítható, hogy a HOT eljárás mérése szerint is a lexikális olvasási út marad a leginkább elérhető a szerzett olvasási zavarban, egyéb tendencia adatainkból nem mutatkozik.

6. táblázat: A HOT olvasásvizsgálat eredményei százalékpontokban

\begin{tabular}{|c|c|c|c|c|c|c|c|c|c|c|c|c|c|c|c|}
\hline 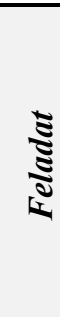 & 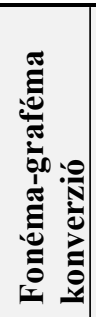 & 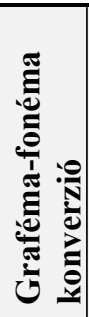 & 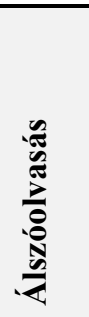 & 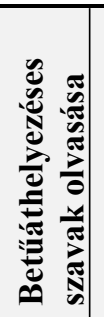 &  & 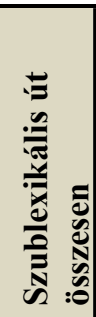 & 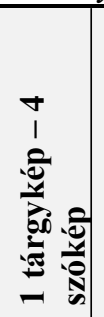 & 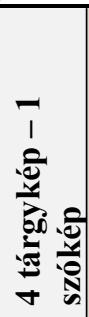 & 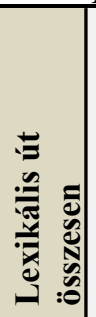 & 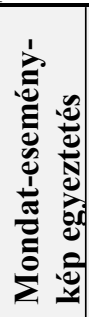 & 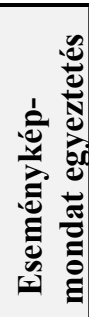 & 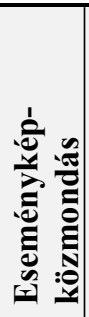 & 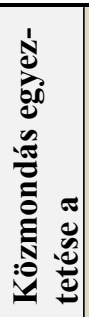 & 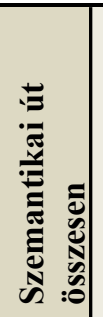 & 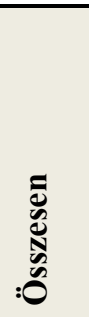 \\
\hline 1. & 87,5 & 100 & 75 & 3,3 & 100 & 85,9 & 10 & 100 & 100 & 75 & 100 & 10 & 60 & 83,3 & 0 \\
\hline 2. & 100 & 100 & 15 & 66,7 & 100 & 92, & 77,8 & 77,8 & 7,8 & 75 & 75 & 100 & 60 & 77,8 & 2,8 \\
\hline 3. & 95,8 & 95,8 & 31,3 & 13,3 & 100 & 73, & 10 & 100 & 100 & 100 & 15 & 10 & 4( & 7,8 & \\
\hline 4. & 12,5 & 16 & 0 & 0 & 0 & & 2,2 & 2,2 & 72 & 25 & 7,5 & 50 & & 7,8 & 6 \\
\hline 5. & 45,8 & 5,8 & 1, & 13,3 & 95 & 66,1 & 10 & 100 & 10 & 75 & 100 & 10 & 100 & 4,4 & 7,0 \\
\hline 6. & -1, & 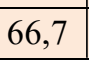 & & 0 & 25 & 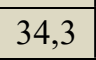 & 66,7 & 100 & 83 , & 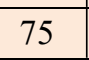 & 52,5 & 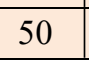 & 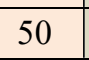 & 8,3 & 58,6 \\
\hline 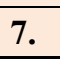 & 100 & 100 & 3,8 & 6,7 & 100 & 93,9 & 88,9 & 100 & 94,4 & 100 & 100 & 100 & 60 & 88,9 & 92,4 \\
\hline
\end{tabular}

Eredményeink alapján elmondható, hogy a HOT eljárással vizsgálva egyik résztvevő sem érte el a maximális pontszámot illetve a $100 \%$-ot, tehát ez a teszt is minden betegünknél olvasászavart jelzett.

\section{Elemzés}

Megállapítható tehát, hogy mindkét olvasásvizsgáló eljárás olvasási zavart jelzett az általunk vizsgált afáziás betegeknél. Nézzük meg azonban az egyes olvasási utakon elért összesített eredményeket a két teszt összevetésével.

A 7. táblázat adataiból kiolvasható, hogy mindkét eljárás esetében a lexikális szinten születtek a legjobb, míg a szublexikális szinten a leggyengébb eredmények a 7 beteg átlagában. Továbbá, míg az összes feladat viszonylatában, valamint a lexikális és a szemantikai szinten a két eljárás hasonló teljesítményeket mért, addig a szublexikális szinten a WAB sokkal rosszabb eredményt jelez, mint a HOT. Ennek oka lehet, hogy mint említettük, a WAB szublexikális szinthez rendelt feladatai nem annyira az olvasás, mint inkább a fonológiai tudatosság müködését mérik.

6. táblázat: A WAB olvasásvizsgáló eljárás és a HOT eljárás eredményeinek olvasási utak szerinti összehasonlitása

\begin{tabular}{|c|c|c|}
\hline & WAB-olvasás & HOT \\
\hline Szublexikális szint & $48,4 \%$ & $67,0 \%$ \\
\hline Lexikális szint & $91,6 \%$ & $89,7 \%$ \\
\hline Szemantikai szint & $71,9 \%$ & $72,6 \%$ \\
\hline Teljes eljárás & $70,6 \%$ & $76,5 \%$ \\
\hline
\end{tabular}


Fenti probléma az egyes betegek egyéni eredményének összehasonlításával még szembetünőbbé válik. A 2. ábrán a szublexikális utat jelölő oszlopok a WAB és a HOT diagramján az 1., a 2., a 4., az 5. és a 6 . beteg esetében feltünő, 12-60 százalékpontos különbségeket mutatnak, a 4 . beteg kivételével a HOT javára. A 4. beteg súlyos motoros (szenzomotoros) afáziában szenved, az olvasási képesség nála szinte teljesen elveszett, vizuális percepciója és memóriája azonban jól müködik. A többiek nyelvi zavara középsúlyos illetve enyhe fokú. Klinikai tapasztalatunk szerint ilyen esetekben a szublexikális olvasási út sérül ugyan, de csak kisebb mértékben, míg a fonológiai tudatosság sokszor erőteljesen károsodik.

Tegyük még hozzá ehhez, hogy bár felnőtt korára a legtöbb ember rutinos olvasóvá válik, és mindhárom olvasási út használatára - így a szó szintje alatti olvasásra (graféma-fonéma egyeztetésre, betüzésre, betük összeolvasására) is - képes, a fonológiai tudatosság szintje illetve a fonetikai, fonológiai egységekkel való manipuláció képessége egyes, diszlexiával nem diagnosztizált egészséges személyeknél is meglepően alacsony. Meglehet, hogy a WAB H. és J. feladatában gyengén teljesítők a megbetegedésük előtt sem teljesítettek (volna) jól a fonológiai tudatosság feladataiban.

A szó szintü olvasási úton mért jó teljesítmények reálisak, amennyiben tekintetbe vesszük, hogy a lexikális mindkét eljárás hétköznapi fogalmakkal dolgozik, ráadásul a WAB esetében a többszörösen ismétlődő (és a szóbeli tesztből is ismerős) itemek, a HOT-ban pedig színes képek segítik a szóképek azonosítását.

A gyakorló logopédus számára azonban meglepőek a lexikális szinten elért igen jó eredmények. Tapasztalataink szerint ugyanis az olvasási zavarral küzdő afáziás betegek valóban elsősorban izolált szóképek ábraszerü felismerésére, azaz szóképolvasásra képesek. Ha mondatokat, több mondatból álló egységeket végigolvasnak - kisilabizálnak - is, az (akár néma, de föként a hangos) olvasás technikai megvalósítása többnyire annyira leterheli a kognitív rendszert, hogy arról már nem tudnak számot adni, mit olvastak.

2. ábra: A WAB olvasásvizsgálat és a HOT eljárás eredményei oszlapdiagramon

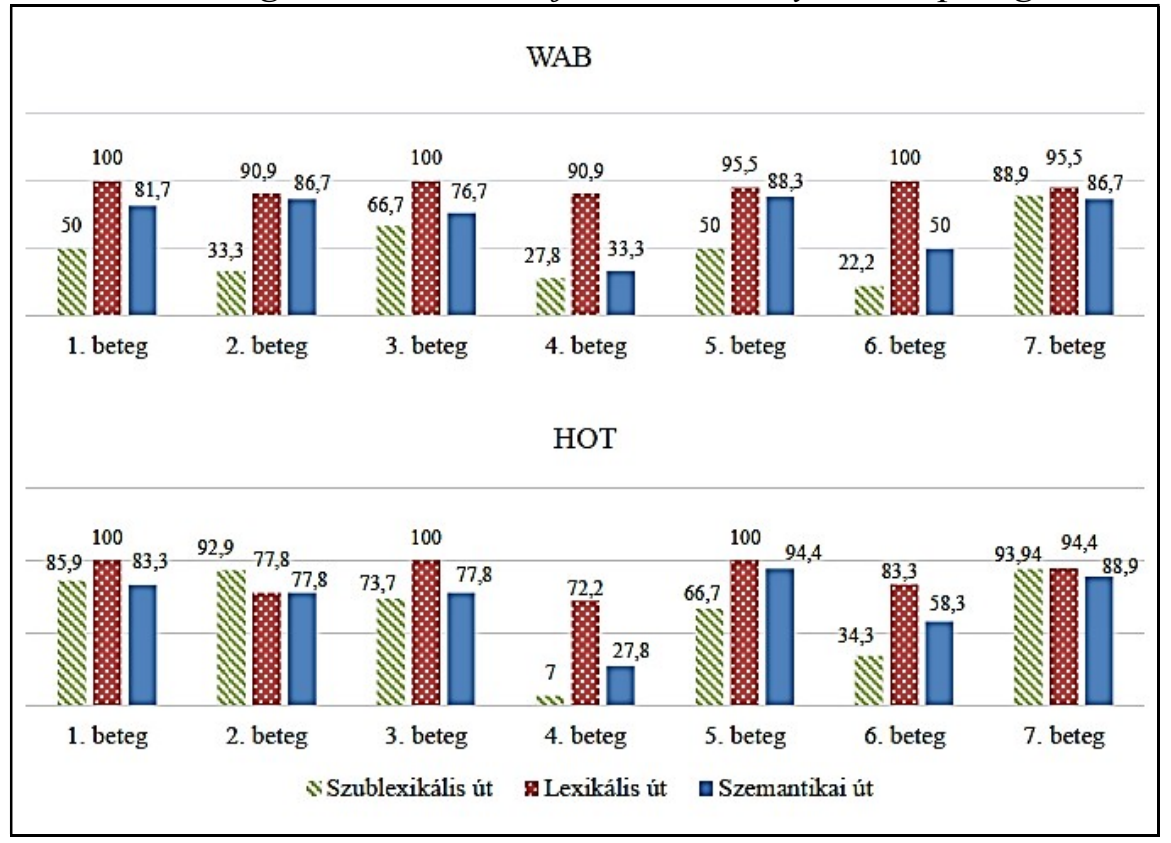




\section{KÖVETKEZTETÉSEK, TOVÁBBI FELADATOK}

A WAB olvasásvizsgálat és a Háromutas Olvasásvizsgáló Teszt együttes alkalmazásával végzett felméréseink eredményei alapján kutatási céljainkkal kapcsolatban a következőket állapíthatjuk meg.

Bebizonyosodott, hogy bár a HOT eszközigényesebb eljárás, megfelelő előkészítés esetén alkalmazása nem okoz nehézséget sem a vizsgálatvezetőnek, sem a vizsgált személynek. Az eszközök kivitelükben a stroke-on átesett betegek szükségleteihez igazodnak, az utasítások egyszerüek, érthetőek, könnyen kivitelezhetőek. Tapasztalatunk tehát, hogy bár a HOT alaposabb előkészületet kíván, a két vizsgálóeljárás felvétele és értékelése adott beteg esetében nagyjából ugyanannyi időt vesz igénybe.

A gyakorlatban is kiderült, hogy a HOT értékelése áttekinthetőbb, egyértelmübb, mint a WAB olvasásvizsgálatáé, mivel minden feladat minden iteménél csak egy jó megoldás fogadható el, egy-egy feladaton belül az egyes itemek azonos pontszámot érnek, valamint adott feladatoknál az olvasástechnika és az olvasásértés külön pontozandó.

A két felmérésben összességében hasonló eredményeket kaptunk, betegeinknél mindkét vizsgálóeljárás jelezte az olvasási zavart. Korábbi feltevéseinkkel ellentétben megállapíthatjuk, hogy a feladatok csoportosítása által a WAB olvasásvizsgálat is alkalmassá tehető az egyesített szófelismerési modell által indikált három olvasási út közül a lexikális és a szublexikális szinten nyújtott teljesítmény mérésére. A szublexikális szint vizsgálatára azonban nem alkalmas, mivel a rendelkezésre álló három feladat közül kettő nem az olvasási, hanem a fonológiai manipulációs képességet teszteli. Mindazonáltal eredményeinkböl arra következtetünk, hogy összességében a HOT differenciáltabb képet ad az egyes olvasási utak funkcióképességéről, mint a WAB, ezzel lehetővé teszi az olvasási zavar minőségének és mértékének meghatározását, ami megkönnyíti a terápiás folyamat tervezését.

A Háromutas Olvasásvizsgáló Teszttel lefolyatott első vizsgálataink az eljárás gyenge pontjaira is rámutattak. Bár a feladatok és az eszközök kidolgozására nagy hangsúlyt fektettünk, beláttuk, hogy a 7. feladatban a disztraktor mondatok és képek nem mindenben felelnek meg a leírásban szereplő tulajdonságoknak. Igaz, ez a feladat relevanciájára nincs hatással, mégis a szabatosság érdekében a továbbiakban az anyagnak ezt a részét korrigálnunk kell.

Az olvasási szintek mentén továbbgondolkodva úgy látjuk, hogy a szublexikális szinthez tartozó ún. átmeneti feladatok (4. és 5. feladat) értékelésénél nagy hangsúlyt kell fektetnünk a hibázások elemzésére - fentebb ismertetett első vizsgálataink esetében ez nem történt meg -, hogy adott betegnél a szublexikális vs. lexikális út müködéséröl pontosabb képet kapjunk.

Első vizsgálataink további hiányossága az olvasási időeredmények értékelése. Jelen tanulmányban azért mellőztük az idői adatok közlését, mert úgy véljük, ezek csak az ép olvasóktól nyert adatok fényében volnának értelmezhetőek. Ugyanez vonatkozik a teljesítményszintek megállapítására is. Mint a HOT eljárás bemutatásakor elmondtuk, az ép olvasó személyek olvasásvizsgálata jelenleg zajlik.

Összességében eljárásunk jelenleg arra alkalmas, hogy megállapítsuk, afáziás betegeinknél az egyes olvasási utak a hibátlan teljesítményhez képest milyen szinten müködnek, közülük melyik az az út, amelyre a terápia felépíthető, s melyik olvasási út irányába folytatódjék.

\section{IRODALOM}

Ahlsén, E. (2006). Introduction to neurolinguistics. Philadelphia: John Benjamins Publishing Company.

Ans, B., Carbonnel, S. \& Valdois, S. (1998). A connectionist multiple-trace memory model for polysyllabic word reading. Psychological Review. 105. pp. 678-723. 
Baddeley, A. D. (2003). Working memory and language: an overview. Journal of Communication Disorders. 36. 189-208.

Basso, A. (1989). Therapy of aphasia. In Boller, F. \& Grafman, J. (eds.) Handbook of Neuropsychology. Vol 2. pp. 67-82. Amsterdam: Elsevier.

Beeson, P. M. \& Rapcsak, S. Z. (2006). Treatment of alexia and agraphia. In J. H. Noseworthy (ed.) Neurological therapeutics: Principles and practice. Second edition. London: Martin Dunitz. pp. 3045-3060.

Brown, J. I., Fishco, V. V. \& Hanna, G. S. (1993). Nelson-Denny Reading Test. Itasca, IL: Riverside Publishing.

Carlomagno, S., Iavarone, A. \& Colombo, A. (1995). Cognitive approaches to writing rehabilitation: From single case to group studies. In Riddoch, M.J. \& Humphreys G. W. (eds.) Cognitive Neuropsychology and Cognitive Rehabilitation. Hillsdale, NJ: Lawrence Erlbaum Associates. pp. 485-502.

Carr, T. H. \& Pollatsek, A. (1985). Recognizing printed words. A look at current models. In Besner, D., Waller, T. G. \& MacKinnon, G. E. (eds.) Reading research: Advances in theory and practice. 5. San Diego, CA: Academic Press, pp. 1-82.

Cherney, L. R. (2004). Aphasia, alexia and oral reading. Topics in Stroke Rehabilitation, 1. pp. 22-36.

Code, C. (1987). Language, aphasia and the right hemisphere. Chichester: Wiley.

Code, C. (1996). Speech from the isolated right hemisphere? Left hemispherectomy cases E. C. and N. F. In Code, C., Wallesch, C-W., Joanette, Y. \& Lecours, A-R. (eds.) Classical cases in neuropsychology. Hove: Lawrence Erlbaum Associates. pp.319-336.

Code, C. (1997). Can the right hemisphere speak? Brain and Language. 57. pp. 38-59.

Coltheart, M., Rastle, K., Perry, C., Langdon, R. \& Ziegler, J. (2001). DRC: A Dual Route Cascaded model of visual word recognition and reading aloud. Psychological Review. 108. pp. 204-256.

Coslett, H.B., Rothi, L.J.G., \& Heilman, K.M. (1985). Battery of Adult Reading Function. Unpublished test. University of Florida.

Csépe V. (2006). Az olvasó agy. Budapest: Akadémiai Kiadó.

Dennis, M.\& Kohn, B. (1975). Comprehension of syntax in infantile hemiplegics after cerebral hemidecortication: Left hemisphere superiority. Brain and Language. 2. pp. 472482.

Ellis, A. W. (2004). Olvasás, írás, diszlexia. Budapest: TAS-11 Kft.

Friedman, R. B. (2002). Clinical diagnosis and treatment of reading disorders. In Hillis, A. E. (ed.) The Handbook of Adult Language Disorders. New York: Psychology Press, pp. $27-$ 43.

Galaburda, A. M. \& Kemper, T. L. (1979). Cytoarchitectonic abnormalities in developmental dyslexia: A case study. Annals of Neurology. 6. pp. 94-100.

Galaburda, A. M., Sherman, G. F., Rosen, G. D., Aboitiz, F. \& Geschwind, N. (1985). Developmental dyslexia: Four consecutive patients with cortical anomalies. Annals of Neurology. 18. pp. 222-233.

Gazzaniga, M. S. (1983). Right hemisphere language following brain dissection: A 20 year perspective. American Psychologist. 38. pp. 525-537.

Goodglass, H., Kaplan, E. \& Barresi, B. (2000). Boston Diagnostic Aphasia Examination. Third edition. Ausin, TX: Pro-Ed.

Goodman, R. A. \& Caramazza, A. (1986). The Johns Hopkins Dyslexia Battery. Baltimore: Johns Hopkins University Press.

Gósy M. (2005). Pszicholingvisztika. Budapest: Osiris Kiadó.

Grainger, J. \& Jacobs, A. M. (1996). Othographic processing in visual word recognition. A multiple read-out model. Psychological Review. 103. pp. 518-565. 
Harm, M. W. \& Seidenberg, M. S. (1999). Phonology, reading acquisition and dyslexia. Insights from connectionist models. Psychological Review. 106. pp. 491-528.

Harm, M. W. \& Seidenberg, M. S. (2004). Computing the meaning of words in reading. Cooperative division of labor between visual and phonological processes. Psychological Review. 111. pp. 662-720.

Helm-Estabrooks, N., Albert, M. L. \& Nicholas, M. (2004.) Manual of Aphasia and Aphasia Therapy. Third edition. Austin: TX, Pro-Ed.

Hillis, A. E. (2007). Alexia and agraphia in acute and chronic stroke. In Godefroy, O. \& Bogousslavsky, J. (eds.) The behavioral and cognitive neurology of stroke. Cambridge: University Press. pp. 102-125.

Juhász Á. (szerk.)(2007). Logopédiai vizsgálatok kézikönyve. Budapest: Logopédia Kiadó.

Kay, J., Lesser, R. \& Coltheart, M. (1992). PALPA: Psycholinguistic Assessments of Language Processing in Aphasia. Hillsdale, NJ: Lawrence Erlbaum.

Kertesz, A. (1982). Western Aphasia Battery. New York: Harcourt Brace Jovanovich Krasznárné Erdős F. \& Feketéné Gacsó M. (2005). Az afáziás betegek vizsgálata, dokumentációja. In Krasznárné Erdős F. \& Feketéné Gacsó M. (szerk.) Tanulmányok az afázia témaköréből. Budapest: Eötvös József Könyvkiadó. 33-39.

LaPointe, L. L. \& Horner, J. (1998). Reading Comprehension Battery for Aphasia. Second edition. Austin, TX: Pro-Ed.

Levin, H. (1979). The eye-voice span. Cambridge, MA: MIT Press.

MacGinitie, W. H., MacGinitie, R. K., Maria, K. \& Dreyner, L. G. (2000). Gates-MacGinitie Reading Tests. Fourth edition. Itasca, IL: Riverside Publishing.

McClelland, J. L. \& Rummelhart D. E. (1981). An interactive activation model of context effects in letter perception. Part 1. An account of basic findings. Psychological Rewiev. 88. pp. 375-407.

Morton, J. (1964). A model for continuous language behaviour. Language and Speech. 7. pp. 40-70.

Net 1.: WAB Olvasásvizsgálat. letöltés: 2016.09.12. http://www.afazia.info/terapiat-segitolehetosegek/tesztek/afaziat-vizsgalok 1/WABOlvas\%C3\%A1sVizsg\%C3\%A1lata.rtf?attredirects $=0 \& \mathrm{~d}=1$

Norris, D. (1994). A quantitative multiple-levels model of reading aloud. Journal of Experimental Psychology, Human Perception and Performance. 20. pp. 1212-1213.

Norris, D. (2006). The Bayesian Reader: Explaining word recognition as an optimal Bayesian decision process. Psychological Review. 113. pp. 327-357.

Obregón, A. G. (2008). Remaining literacy competence: A sociopsycholinguistic view of reading in aphasia. In Flurky, A. D., Paulson, E. J.\& Goodman, K. S. (eds.). Scientific Realism in Studies of Reading. Routledge. pp. 85-108.

Ogden, J. A. (1996). Phonological dyslexia and phonological dysgraphia following left and right hemispherectonomy. Neuropsychologia. 34. pp. 905-918.

Osmanné Sági J. (1983). A DeRenzi-féle Token beszédmegértési teszt adaptálásának eredményei. Magyar Pszichológiai Szemle. 1983/5. 407-420.

Osmanné Sági J. (1997). Az afáziák neurolingvisztikai alapjai. Budapest: Nemzeti Tankönyvkiadó.

Osmanné Sági J. (2007): Az afázia vizsgálata. In Juhász Ágnes (szerk): Logopédiai vizsgálatok kézikönyve. Budapest: Logopédiai Kiadó. 139-153.

Paap, K. R., Newsome, S. L., McDonald, J. E. \& Schvaneveldt R. W. (1982). An activationverification model for letter and word recognition. The word-superiority effect. Psychological Rewiev. 89. pp. 573-594. 
Pataky I. (2005). Élet a stroke után: A neuropszichológiai deficitek kezetléséröl. In Krasznárné Erdős F. \& Feketéné Gacsó M. (szerk.) Tanulmányok az afázia témaköréböl. Budapest: Eötvös József Könyvkiadó. 118-137.

Plaut, D., McClelland, J. M., Seidenberg, M. S. \& Patterson, K. (1996). Understanding normal and impaired word reading. Computational principles in quasi-regular domains. Psychological Review. 103. pp. 56-115.

Pollatsek, A. \& Rayner, K. (1989). Reading. In Posner, M. (ed.) Foundations of cognitive science. Cambridge, MA: MIT Press. pp. 401-436.

Racsmány M. (2004). A munkamemória szerepe a megismerésben. Budapest: Akadémiai Kiadó.

Rayner, K. \& Reichle, E. D. (2010). Models of the reading process. Wiley Interdisciplinary Reviews: Cognitive Science. Vol 1.. Issue 6. pp. 787-799.

Reilly, R. \& Radach, R. (2006). Some empirical tests of an interactive activation model of eye movement control in reading. Cognitive System Research. 7. pp. 34-55.

Seidenberg, M. S. \& McClelland, J. L. (1989). A disturbed, developmental model of word recognition and naming. Psychological Review. 96. pp. 523-568.

Smith, A.\& Sugar, O. (1975). Development of above normal language and intelligence 21 years after left hemispherectonomy. Neurology. 25. pp. 813-818.

Swanberg, M. M., Nasreddine, Z. S., Mendez, M. F. \& Cummings, J. L. (2007). Speech and Language. In Goetz, C. G. (ed.) Textbook of clinical neurology. Third edition. Philadelphia: Saunders Elsevier. pp. 79-98.

Tóth L. (2002). Az olvasás pszichológiai alapjai. Debrecen: Pedellus Tankönyvkiadó

Weekes, B. (1995). Right hemisphere writing and spelling. Aphasiology. 9. pp. 305-319.

Weekes, B., Coltheart, M. \& Gordon, E. (1997). Deep dyslexia and right hemisphere reading: A regional cerebral blood flow study. Aphasiology. 12. pp. 1139-1158.

Wiederholt, J. L. \& Bryant, B. R. (2001). Gray Oral Reading Tests - 4. Austin, TX: Pro-Ed.

Woodcock, R. W. (1998). Woodcock Reading Mastery Test-Revised-Normative Update. Circle Pines, MN: American Guidance Service.

Zaidel, E. (1985). Language in the right hemisphere. In Zaidel, D. F. B. \& Zaidel, E. (eds.) The dual brain: Hemispheric Specialisation in Humans. New York: Guildford Press. pp. 205-231.

Zorzi, M., Houghton, G. \& Butterworth, B. (1998). Two routes or one in reading aloud? A connectionist dual-process model. Journal of Experimental Psychology, Human Perception and Performance. 24. pp. 1131-1161. 


\section{MELLÉKLETEK}

1. melléklet

\section{WAB Olvasás Vizsgálata}

\section{A. Olvasott mondatok megértése:}

Instrukció: Olvassa el ezeket a mondatokat, és mutassa meg melyik mondat illik a pontok helyére. Az instrukció megismételhetõ, példa mondat is adható. P1. Hideg a jég, Anyu fózi az ebédet, vacsorát, stb.

1. Édes a....néz, medve méz kas.

2.A katona kezeli a háborút, az ágyat, a fát, az ágyút.

3.Péter a tengerek és a folyók mélyét kutatja. Ỗ egy.......

hal, búvár, bútor, uszoda

4. Elmegyek a szerelöhöz, mert elromlott az autóm..

szine, fék, mosógép, lámpája

5. Jóska bácsi délben felmegy a toronyba. meghúzza a .....

létra, harangot, kötél csengõ

6. A parasztok búzát, árpát és más gabonát termesztenek.

Termeszthetnek még .... tyúkot, gyümölcsöt, szántóföldön, zöldséget

7. Valamikor sok energia állt rendelkezésre. Ma már kevés az olaj, ezért

sok ország más energia forrást keres. Ilyen lehet ..

az atom, a vízözön, a napfény a gazdagság

8. A Titanic egy óceánjáró hajó volt, melyet elsüllyaszthetetlennek gondoltak,

de 1912-ben léket kapott és elsüllxedt több, mint ezer utas halálát okozva.

Ez a katasztrófa nem történt volna meg, ha nem..

merül ki az energiája, ütközik egy jéghegynek,

vitt volna utasokat, tartott volna nyugatnak

Maximális pontszám : 40

Elért pontszám:
2 pont

2 pont

4 pont

4 pont

6 pont

6 pont

8 pont

8 pont 


\section{B. Utasítások olvasása}

Instrukció: olvassa fel hangosan az ideirt utasitásokat, majd hajtsa is végre, ami le van irva!

sorsz parancs olvasás cselekvése

1. Emelje fel a kezét!

2. Integessen!

3. Hunyja be a szemét!

4. Rajzoljon egy keresztet a lábával!

5. Mutasson a székre, azután az ajtóra!

6. Vegye fel a ceruzát, kopogjon harmat, és tegye le!

Maximális pontszám : 20

$\begin{array}{ll}1 & 1 \\ 1 & 1 \\ 1 & 1 \\ 2 & 2 \\ 2 & 2 \\ & \\ 3 & 3\end{array}$

\section{Elért pontszám:}

\section{Transzformált pontszáma:}

A pontszámot transzformáljuk: 60 a maximális pontszámbó1 - kivonjuk a beteg által elért pontszámot, és megszorozzuk 2- vel, és ezt az eredményt kivonjuk 100-bó1 Az A és B feladat együttes pontszáma 50 vagy több, a tesztet nem kell tovább folytatni. Gyakorlatban kell, mert a betũzésnél fog kibukni a probléma, hogy a beteg szóképolvasó!

\section{C. Írott szó alapján tárgy kiválasztása}

WAB tesztböl ismert 6 tárgyat a beteg elé tszzük, a szavakat tartalmazó kártyákat egyenként adjuk a betegnek, s neki meg kell mutatni a megfelelō tárgyat. / csésze, fésü, ceruza, virág, gyufas, csavarhúzó / 


\section{D. Írott szó alapján kép kiválasztása.}

Ismét a hat tárgy képét de egy lapon a beteg elé tesszük, a szavakat ismét egyenként kapja, meg kell mutatni a megfelelö képet.

Maximális pontszám 6

Elért pontszám:

E. Kép alapján írott szó kiválasztása

A szavak listáját a beteg elé tesszük. Ezen kell megmutatni az egyenként mutatott képeknek a nevét

Maximálilis pontszám: 6

Elért pontszám:

F. Kiejtett szó- írott szó összevetése

Öt -öt szót tartalmazó listáról kell kikeresni a hallott szó nevét.

doboz, toboz, koboz, fenyö, makk

géz, ujj, méz, láb, kéz

tálca, tárca, pálca, érme, százas

bika, nád, boka, béka, gólya

Maximális pontszám:4

Elért pontszám:

G. Betü diszkrimináció WAB tesztben lévõ feladat

\section{Maximális pontszám:6 Elért pontszám:}

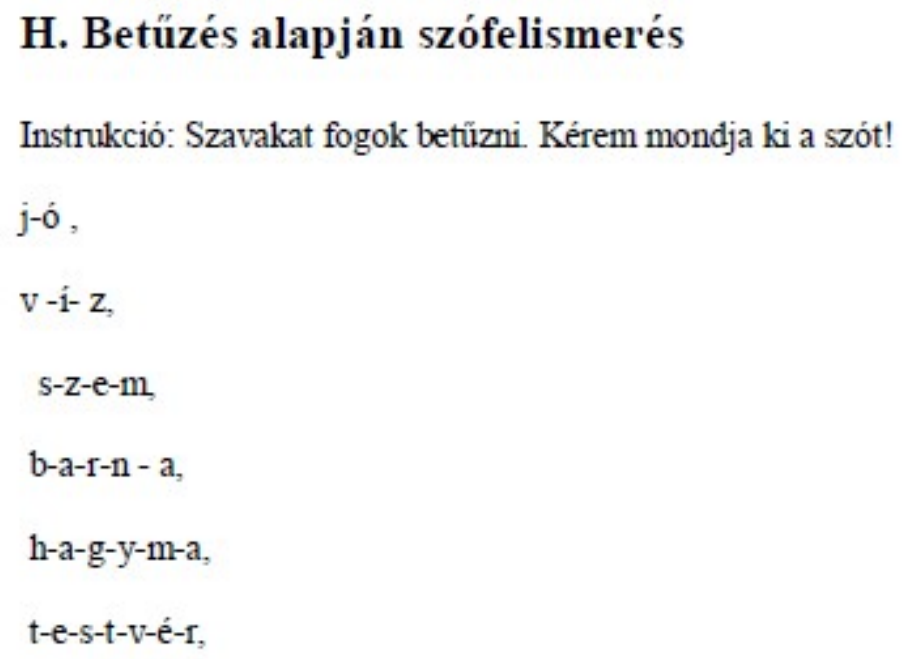

Maximális pontszám:6

Elért pontszám: 


\section{J.Betüzés}

Instrukció: Szavakat fogok mondani legyen szives betüzni : ha,

tej,

pénz,

lány,

testvér,

tisztviselö.

Maximális pontszám: 6

Elért pontszám:

Itt százalékosan kell az eredményt kiszámítani és úgy tálalni az orvosok felé!

2. melléklet

HOT - Dankovics, Molkuolu, Pelyvás, 2016

\section{HÁROMUTAS OLVASÁSVIZSGÁLÓ TESZT (HOT)}

Készítette: Dr. Dankovics Natália, Moluolu Tímea, Pelyvás Károlyné, 2016.

Általános útmutató.

A teszt elsösorban afáziás betegek olvasásvizsgálatára szolgál. Az olvasási készséget a mondat, a szó és a szó alatti fonológiai szinten méri, igy nem az összesitett eredmény a fontos, hanem az egyes szintek teljesitményének kïlön-külön értékelése lényeges! Ezen részeredmények alapján ugyanis a terápia menete jól tervezhetõ.

Az eszközöket a következöképpen készitsük el:

Betütípus: Arial, félkövér. Betüméret: a betükártyák esetében 48 pt, a szó- és mondatkártyák esetében 32 pt. A képek mérete: Egy A4-es lapra 4 képet illesszünk be! Célszerũ az eszközöket laminálni. A képeket a melléklet tartalmazza.

A tesztet egyéni helyzetben vesszüik fel. A betükártyákat, szóképeket, tárgyképeket, mondatkártyákat és eseményképeket elöre kikészitjük. $\mathrm{Az}$ itemeken belül a szó- illetve képanyagokat random sorrendben helyezzük a beteg elé. Az utasitásokat röviden, egyértelmüen, közepes beszédtempóval adjuk $\mathrm{A}$ válaszokat menet közben - minél kevésbé feltũnöen - lejegyezzük, lehetöség szerint készítsünk hang- vagy videofelvételt. Lehetöleg ne segítsünk a betegnek a megoldásban, ha mégis segítïnk, ezt jegyezzük fel a vizsgálati lapra!

Értékelés: Minden helyes válaszra 1 pontot acunk. A lexikális és a szemantikai szint feladataiban a helyesen olvasott itemekért újabb 1-1 pont jár. (Ha a beteg adott feladatban kimondja a helyes megoldást, de hibásan választja li a szóképet vagy a mondatkártyát, azt följegyezzük, de pontot nem adunk rá.) Az olvasási idöt a szublexikális szinten az 1-2. feladatban a feladatonként mérjük, a 3-5. feladatban pedig az adott szótagszámú itemek elolvasásával töltött idötartamokat mérjük meg. A lexikális olvasási út idejét úgy mérjük, hogy az egyes szófajokhoz tartozó 3-3 item megoldásával töltött idöt egybe számítjuk, a szemantikai út esetében pedig az egyes mondatok kiolvasásának idejét mérjük meg.

A pontszámokat olvasási szintenként (szublexikális szint, lexikális szint, szemantikai szint), összesitjük, végül a három szint eredményét is összeadjuk, igy megkapjuk a nyerspontokat. Az értékelhetöség végett a nyerspontolból százalélpontokat számitunk a maximális pontszámok fiuggvényében. 
HOT - Dankovics, Mokuolu, Pelyvás, 2016

Beteg neve:

életkora:

afázia típusa és súlyossága, fõbb tūnetek:

I. SZUBLEXIKÁLIS ÚT

Összesen $99 \mathrm{p}$

Pontszám:

1. Graféma-fonéma konverzió. Egy kártyát teszünk a beteg elé, melyen 24 darab betũ áll. Ezek közül kell felismernie és megmutatnia azt, amit a vizsgálatvezetö mondott.

Instrukció: Mutasson arra a betî̉re, amit mondok!

Összesen $24 \mathrm{p}$

Helyes válaszok száma:

Pontszám:

\begin{tabular}{|c|c|c|c|c|c|}
\hline $\mathrm{e}$ & $\mathrm{d}$ & $\mathrm{ny}$ & $\mathrm{g}$ & $\mathrm{a}$ & $\mathrm{cs}$ \\
\hline $\mathrm{b}$ & $\mathrm{h}$ & $\mathrm{z}$ & $\mathrm{n}$ & $\mathrm{i}$ & $\mathrm{m}$ \\
\hline$\dot{\mathrm{e}}$ & $\mathrm{k}$ & $\mathrm{p}$ & $\mathrm{zs}$ & $\mathrm{ty}$ & $\mathrm{a}$ \\
\hline $\mathrm{c}$ & $\mathrm{o}$ & $\mathrm{r}$ & $\mathrm{l}$ & $\mathrm{v}$ & $\mathrm{t}$ \\
\hline
\end{tabular}

2. Fonéma-graféma konverzió. A 24 betükártyát egyenként, random sorrendben helyezzük a beteg elé. Megkérjük, hogy olvassa fel, amit a kártyán lát. Instrukció: Olvassa fel hangosan, ami a kártyán van!

Összesen $24 \mathrm{p}$

Helyes válaszok száma:

Pontszám:

\begin{tabular}{|c|c|c|c|c|c|}
\hline I & v & p & gy & f & ty \\
\hline á & s & n & o & h & j \\
\hline ü & cs & c & b & z & sz \\
\hline g & é & a & d & r & m \\
\hline
\end{tabular}

3. Álszóolvasás. A 16 szóképet egyenként, random sorrendben helyezzük a beteg elé. Megkérjük, hogy olvassa fel, amit a kártyán lát. Instrukció: Olvassa fel hangosan, ami a kártyán van!

Összesen $16 \mathrm{p}$

Helyes válaszok száma:

Pontszám:

\begin{tabular}{|l|l|l|l|}
\hline ped & dolk & íg & önk \\
\hline amon & katázs & solyta & gabom \\
\hline anyavi & tingromás & mizengõ & lügyédik \\
\hline telisbenge & önüdatréf & bekiragyen & Ioncidékma \\
\hline
\end{tabular}


HOT - Dankovics, Mokuolu, Pelyvás, 2016

4. Betüáthelyezéses szavak olvasása. A 15 szóképet egyenként, random sorrendben helyezzük a beteg elé. Megkérjük, hogy olvassa fel, amit a kártyán lát.

Instrukció: Olvassa fel hangosan, ami a kártyán van!

Összesen $15 \mathrm{p}$

Helyes válaszok száma:

Pontszám:

\begin{tabular}{|l|l|l|l|l|}
\hline esesz & tédev & füdrõ & oszor & játkisz \\
\hline kívángás & hedegül & kacsárony & sejletmes & kazaul \\
\hline belücsetes & csolokádé & modakosik & vásorálni & mazarágyat \\
\hline
\end{tabular}

5. Betüáthelyezéses szavak olvasása. A 15 szóképet egyenként, random sorrendben helyezzük a beteg elé. Megkérjük, hogy olvassa fel, amit a kártyán lát.

Instrukció: Olvassa fel hangosan, ami a kártyán van!

Összesen $20 \mathrm{p}$

Helyes válaszok száma:

Pontszám:

\begin{tabular}{|l|l|l|l|}
\hline rúg & lô & él & int \\
\hline álom & játék & mackó & kacsa \\
\hline részvétel & rúgkapál & lakatos & savanyú \\
\hline iskolatárs & sopánkodik & elmosogat & félárnyékos \\
\hline étkezőkocsi & nyakatekert & divatáruház & beleírogat \\
\hline
\end{tabular}

II. Lexikílis ÚT

Összesen 36 p

Pontszám:

6. a) Tárgykép-szókép egyeztetés. Kitesszük itemenként a 4 szóképet random sorrendben a beteg elé (a célszavakat pirossal jelöltük, természetesen a tesztben ezek is fekete szinüek!), majd odaadjuk neki a tárgyképet, és megkérjük, olvassa fel azt a szót, amit a képen lát. A feladatban föneveket, igéket és mellékneveket jelölö fogalmakat használunk, szófajonként 3 3 itemmel.

Instrukció: Melyik szót látja a képen? Olvassa fel!

Összesen 18 p

Helyes válaszok száma:

Helyesen olvasott itemek száma:

Pontszám 
HOT - Dankovics, Mokuolu, Pelyvás, 2016

\begin{tabular}{|c|c|c|c|}
\hline óra & traktor & idő & kóró \\
\hline rózsa & függöny & szirom & morzsa \\
\hline fóka & kifli & pingvin & móka \\
\hline
\end{tabular}

\begin{tabular}{|c|c|c|c|}
\hline iszik & segít & eszik & piszkít \\
\hline olvas & rángat & számol & olvad \\
\hline tereget & viháncol & kiöblít & ereget \\
\hline
\end{tabular}

\begin{tabular}{|c|c|c|c|}
\hline sárga & alma & fehér & spárga \\
\hline magyar & kevés & spanyol & fanyar \\
\hline koros & szegény & ifjú & poros \\
\hline
\end{tabular}

6. b) Szókép-tárgykép egyeztetés. Kitesszüik itemenként a 4 tárgyképet random sorrendben a beteg elé, majd odaadjuk neki a szóképet (a célszavakat pirossal jelöltük, a tesztben ezeket adjuk oda a betegnek, természetesen fekete szinnel!). Megkérjük, olvassa fel a kártyán lévö szót, és mutassa meg, melyik képen van. A feladatban föneveket, igéket és mellékneveket jelölö fogalmakat használunk, szófajonként 3-3 itemmel.

Instrukció: Olvassa fel, ami a kártyán van!' Melyik képen látja a szót?

Összesen $18 \mathrm{p}$

Helyes válaszok száma:

Helyesen olvasott itemek száma:

Pontszám:

\begin{tabular}{|c|c|c|c|}
\hline doboz & kígyó & kosár & toboz \\
\hline asztal & répa & szekrény & paszta \\
\hline sirály & papucs & réce & király \\
\hline
\end{tabular}

\begin{tabular}{|c|c|c|c|}
\hline vasal & épít & stoppol & hasal \\
\hline ásít & rajzol & alszik & fásít \\
\hline dagaszt & vezet & szitál & ragaszt \\
\hline
\end{tabular}

\begin{tabular}{|c|c|c|c|}
\hline kövér & pöttyös & magas & nővér \\
\hline kancsal & kopár & vaksi & kancsó \\
\hline esős & csorba & napos & erôs \\
\hline
\end{tabular}


HOT - Dankovics, Mokuolu, Pelyvás, 2016

III. SZEMANTIKAI ÚT

Összesen $36 \mathrm{p}$

Pontszám:

7. a) Mondat-eseménykép egyeztetés. Kitesszüik itemenként a 4 eseményképet random sorrendben a beteg elé, majd odaadjuk neki a mondatkártyát. Megkérjük, olvassa fel a kártyán lévö mondatot, és mutassa meg, melyik képen van.

Instrukció: Olvassa fel a mondatot! Mutassa meg, melyik képen látja ezt!

Összesen $8 \mathrm{p}$

Helyes válaszok száma:

Helyesen olvasott itemek száma:

Pontszám:

1) Pityu kávét iszik. (A többi képen: Pityu bort iszik, A fiú eszik, A fiú az órán alszik)

2) A kisfiú épitőkockával játszik. (A többi képen: $A$ kisfiú mackóval játszik, $A$ kőmüves falat rak, A gyerek táncol)

3) A nagymama harisnyát köt. (A többi képen: Az asszony felhúzza a harisnyát, $A$ nagymama süteményt süt, $A$ mũvésznő képet fest)

4) A medve halat fogott. (A többi képen: A férfi halat fogott, A medve mézet eszik, A medve biciklizik)

7. b) Eseménykép-mondat egyeztetés. Kitesszüik itemenként a 4 mondatkártyát random sorrendben a beteg elé, majd odaadjuk neki az eseményképet. Megkérjük, mutassa meg, mi történik a képen, és olvassa fel a kártyán lévõ mondatot.

Instrukció: Mi történik a képen? Olvassa fel!

Összesen $8 \mathrm{p}$

Helyes válaszok száma:

Helyesen olvasott itemek száma:

Pontszám:

\begin{tabular}{|l|l|}
\hline A & 1. A róka kergeti a nyulat. \\
\hline & 2. A róka játszik a nyúllal. \\
\hline & 3. A rókát kergeti a nyúl. \\
\hline & 4. Az egér megrágta a kolbászt. \\
\hline B & 1. A háziasszony készíti az ebédet. \\
\hline & 2. A háziasszony megeszi az ebédet. \\
\hline
\end{tabular}


HOT - Dankovics, Mokuolu, Pelyvás, 2016

\begin{tabular}{|l|l|}
\hline & 3. A háziasszonyt kikészítette az ebéd. \\
\hline & 4. A pincér kitöltötte a bort. \\
\hline C & 1. A lány megmossa a fogát. \\
\hline & 2. A lánynak fáj a foga. \\
\hline & 3. A lányt megmosta a foga. \\
\hline & 4. A törülközõ a kötélen szárad. \\
\hline D & 1. A férfi fölaprítja a fát. \\
\hline & 2. A férfi ellopja a fát. \\
\hline & 3. A férfit fölaprózta a fa. \\
\hline & 4. A kályhában ég a tüz. \\
\hline
\end{tabular}

8. a) Eseménykép-közmondás egyeztetés. Öt közmondást tartalmazó mondatkártyát kell a betegnek olyan képekhez hozzárendelnie a betegnek mondatokat, melyek a közmondás szó szerint vett jelentését ábrázolják. Kitesszuilk az 5 képet, majd az öt mondatkártyát random sorrendben a beteg elé (egy-egy sorban vagy oszlopban elhelyezve). Megkérjük, hogy olvassa fel a mondatokat, és tegye öket a megfelelö képhez. Instrukció: Olvassa fel, ami a kártyákon van, és tegye ổket a megfelelö képhez!

Összesen $10 \mathrm{p}$

Helyes válaszok száma:

Helyesen olvasott itemek száma:

Pontszám:

\begin{tabular}{|c|}
\hline Ȧtesik a ló túlsó oldalára. \\
\hline Sok lúd disznót győz. \\
\hline Itatja az egereket. \\
\hline Derült égből villámcsapás. \\
\hline Nagy fába vágja a fejszéjét. \\
\hline
\end{tabular}

8. b) Közmondás egyeztetése a jelentésével. A közmondásokat tartalmazó mondatkártyákat a betegnek ezíttal olyan mondatokhoz kell hozzárendelnie, melyek az adott közmondás jelentését megmagyarázzák. Kitesszük az öt-öt mondatkártyát a beteg elé (két sorban vagy oszlopban), majd megkérjük, olvassa fel hangosan a 


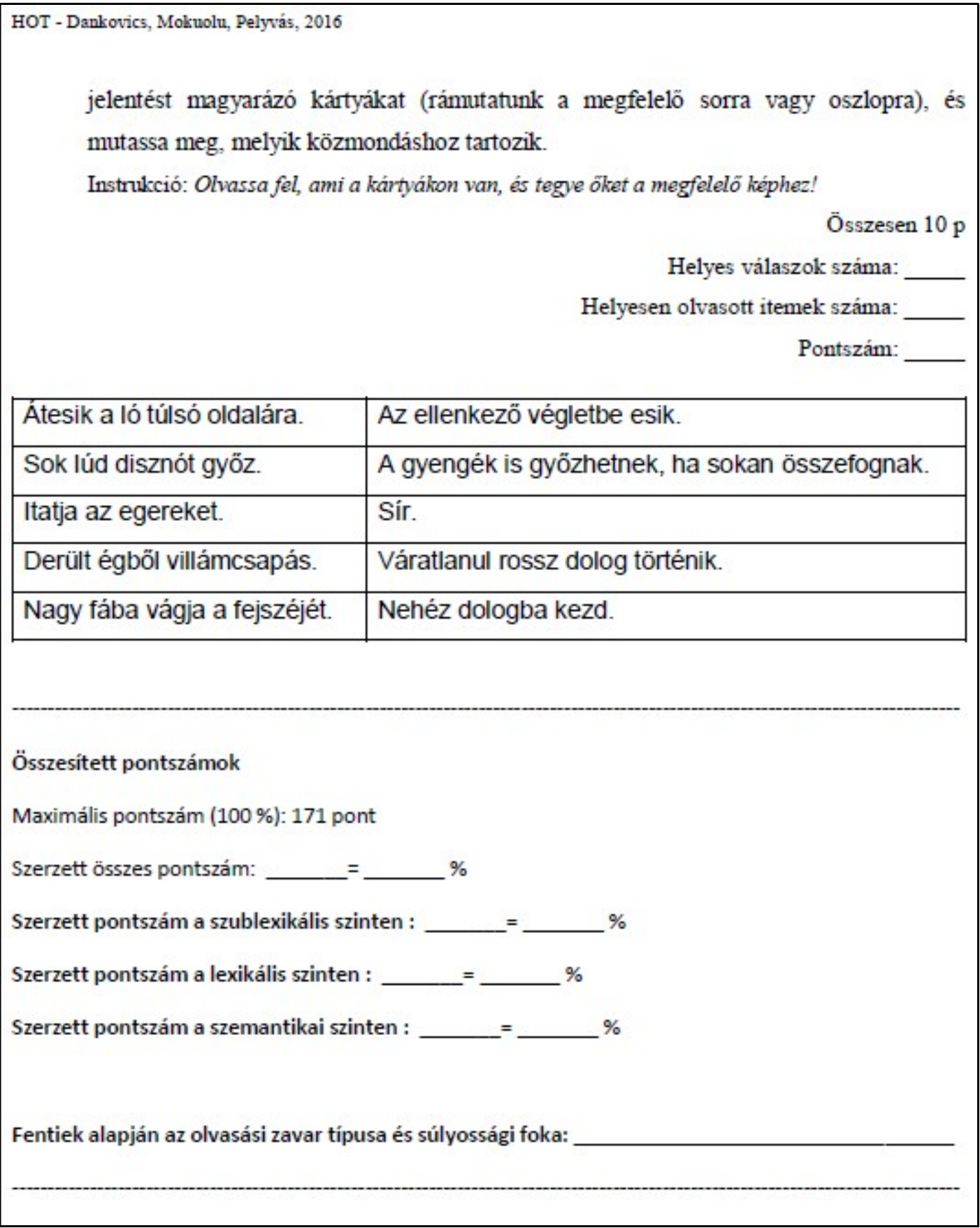

